\title{
EBV-driven B-cell lymphoproliferative disorders: from biology, classification and differential diagnosis to clinical management
}

\author{
Chi Young $\mathrm{Ok}^{1}$, Ling $\mathrm{Li}^{1,2}$ and Ken $\mathrm{H}$ Young ${ }^{1,3}$ \\ Epstein-Barr virus (EBV) is a ubiquitous herpesvirus, affecting $>90 \%$ of the adult population. EBV targets B-lymphocytes and \\ achieves latent infection in a circular episomal form. Different latency patterns are recognized based on latent gene expression \\ pattern. Latent membrane protein-1 (LMP-1) mimics CD40 and, when self-aggregated, provides a proliferation signal via \\ activating the nuclear factor-kappa B, Janus kinase/signal transducer and activator of transcription, phosphoinositide 3-kinase/ \\ Akt (PI3K/Akt) and mitogen-activated protein kinase pathways to promote cellular proliferation. LMP-1 also induces BCL-2 to \\ escape from apoptosis and gives a signal for cell cycle progression by enhancing cyclin-dependent kinase 2 and phosphorylation \\ of retinoblastoma $(\mathrm{Rb})$ protein and by inhibiting p16 and p27. LMP-2A blocks the surface immunoglobulin-mediated lytic cycle \\ reactivation. It also activates the Ras/PI3K/Akt pathway and induces $\mathrm{Bcl}-\mathrm{xL}$ expression to promote $\mathrm{B}$-cell survival. Recent studies \\ have shown that ebv-microRNAs can provide extra signals for cellular proliferation, cell cycle progression and anti-apoptosis. EBV \\ is well known for association with various types of B-lymphocyte, T-lymphocyte, epithelial cell and mesenchymal cell neoplasms. \\ B-cell lymphoproliferative disorders encompass a broad spectrum of diseases, from benign to malignant. Here we review our \\ current understanding of EBV-induced lymphomagenesis and focus on biology, diagnosis and management of EBV-associated \\ B-cell lymphoproliferative disorders.
}

Experimental \& Molecular Medicine (2015) 47, e132; doi:10.1038/emm.2014.82; published online 23 January 2015

\section{INTRODUCTION}

Epstein-Barr virus (EBV) is a ubiquitous double-stranded DNA virus that belongs to the family Herpesviridae and subfamily Gammaherpesvirinae. Gammaherpesvirinae includes two important human gammaherpesviruses, EBV (also known as human herpesvirus 4) and Kaposi's sarcoma-associated herpes virus (also known as human herpesvirus 8 (HHV8)). EBV is a $\gamma-1$ herpes virus, characterized by a tropism for B-lymphocytes with latent infection in the host and the capacity for transforming B-lymphocytes. More than $90 \%$ of the population worldwide carry the virus. EBV was first discovered in a Burkitt lymphoma (BL)-derived cell line by Michael Epstein, Yvonne Barr and Bert Achong in 1964 by electron microscopy. ${ }^{1}$ Almost all EBV-seropositive hosts shed virus in the saliva, and infection occurs when an EBV-naive person is exposed to EBV-rich saliva. ${ }^{2}$ Oropharyngeal epithelium is an entry point for EBV via the immunoglobulin (Ig) A-EBV complex to IgA receptors on the epithelium, and active viral replication (lytic infection) occurs there. ${ }^{3,4}$ The virus spreads out from the infected cells and directly infects nearby B-lymphocytes via viral enveloping of glycoprotein gp 350 to the B-lymphocyte surface molecule CD21. ${ }^{5}$ Penetration of the virus requires interaction between viral gp 42 (which makes a complex with $\mathrm{gH}$ and gL) and HLA-DR on B-lymphocytes. ${ }^{6}$ Indirectly, the infected epithelium can transmit the virus to B-lymphocytes. In infected B-cells, the linear genome circularizes and remains latent as episome in the nucleus (latent infection). Only a small proportion of the latently infected B-lymphocytes undergo viral replication spontaneously.

The EBV genome is a linear-shaped DNA of approximately $172 \mathrm{~kb}$, encoding approximately 100 viral proteins. At both termini of the linear genome, there are variable numbers of $0.5-\mathrm{kb}$ tandem repeats. ${ }^{7}$ In the lytic cycle, most of the EBV viral proteins are expressed but are kept in check by the host immune response. In contrast, only a handful of genes are expressed during latent infection: six EBV nuclear antigens

\footnotetext{
${ }^{1}$ Department of Hematopathology, The University of Texas MD Anderson Cancer Center, Houston, TX, USA; ${ }^{2}$ Department of Medical Oncology, University of Zhengzhou School of Medicine, Zhengzhou, China and ${ }^{3}$ The University of Texas School of Medicine, Graduate School of Biomedical Sciences, Houston, TX, USA

Correspondence: Dr KH Young, Department of Hematopathology, The University of Texas MD Anderson Cancer Center, 1515 Holcombe Boulevard, Houston, TX 77030-4009, USA.

E-mail: khyoung@mdanderson.org

Received 11 September 2014; accepted 1 October 2014
} 
(EBNA-1, 2, 3A, 3B, 3C and LP), three latent membrane proteins (LMP-1, 2A and 2B), and non-coding RNA (EBVencoded small RNA (EBER)-1 and 2). EBNA-1 binds to viral DNA and maintains its episomal form. ${ }^{8}$ EBNA-2 transactivates LMP-1 via interaction with the cellular DNA-binding protein Jк or PU.1. ${ }^{9}$ Because LMP-2B shares the EBNA-2 responsive promoter with LMP-1, EBNA-2 can also upregulate LMP-2B. ${ }^{10}$ Three different isoforms exist in EBNA-3, and they inhibit EBNA-2-mediated upregulation of LMP-1. ${ }^{11}$ EBNA-LP enhances the function of EBNA-2 to transactivate LMP-1. LMP-1 is oncogenic in vivo without expression of the other EBV gene and functionally mimics CD40, which is involved in B-cell activation and proliferation. ${ }^{12,13}$ It is a sixtransmembrane integral protein with a 200 amino-acid C-terminal cytoplasmic tail. This tail includes two important domains, C-terminal activation region 1 (CTAR1) and CTAR2. The transmembrane domain provides a platform for LMP-1 oligomerization, which results in constitutive activation of the molecule. Constitutively activated LMP-1 allows CTAR1 and CTAR2 to interact with downstream molecules, such as tumor necrosis factor receptor-associated factors (TRAFs) to activate the nuclear factor-kappa B (NF-кB) pathway. ${ }^{14}$ LMP-1 also activates the phosphoinositide 3-kinase (PI3K)/Akt pathway, c-Jun N-terminal kinase/AP-1, bcl-2, and A20, which inhibits p53-associated cell death. ${ }^{15-19}$ Cell cycle dysregulation can be caused by LMP-1 (Figure 1). ${ }^{20}$

LMP-2 has two isoforms, LMP-2A and LMP-2B. The genes for LMP-2A and LMP-2B span across the terminal repeats, so they are transcribed only when EBV is in circular form. ${ }^{21}$ They share 12 membrane-spanning domains and a 27 amino-acid C-terminal cytologic domain. Both LMP-2A and LMP-2B have EBNA-2 responsive promoters that have sites for RBP-Jk and PU.1, but their promoters are 3-kb apart. ${ }^{10}$ LMP-2A has an $\mathrm{N}$-terminal cytoplasmic tail that binds to Lyn via SH2-binding motif and Syk via ITAM (immunoreceptor tyrosine-based activation motif). ${ }^{22}$ However, the $\mathrm{N}$-terminal cytoplasmic domain in LMP-2A is lacking in LMP-2B. ${ }^{23}$ In B-lymphocytes, surface Ig (sIg)-mediated EBV lytic reactivation from latent infection can be induced via those protein tyrosine kinases. ${ }^{24}$ However, LMP-2A blocks the sIg-mediated lytic reactivation and therefore acts as a dominant-negative inhibitor of the sIgassociated protein tyrosine kinases. LMP-2A increases $\mathrm{Bcl}-\mathrm{xL}$ expression and activates the Ras/PI3K/Akt pathway to mediate B-cell survival. ${ }^{25,26}$ It also potentiates MYC-induced hyperproliferation by downregulating p27 in a proteasome-dependent manner. ${ }^{27}$ LMP-2B modulates LMP-2A in vitro, but its function in vivo is largely unknown. ${ }^{28}$ The function of EBERs is not clear, but EBERs are transcribed up to $10^{7}$ copies per cell in all forms of EBV latency. ${ }^{29}$ Currently, in situ hybridization for EBER is the most reliable method for morphological detection of latent EBV infection. ${ }^{30}$ On the basis of the latent gene expression, three different latency patterns are recognized. In type I latency, EBER and EBNA-1 are expressed. In type II latency, LMP-1, LMP-2A and LMP-2B are additionally expressed. In type III latency, all latent genes are expressed. Particular diseases with specific latency patterns are shown in Table 1.

Recent studies have expanded our knowledge of EBV microRNAs (miRNAs). EBV was the first virus in which miRNA was found. ${ }^{31}$ At the time of writing, 44 mature ebvmiRs have been recognized (Sanger miRBase library, release 20.0, http://www.mirbase.org/cgi-bin/query.pl?terms = EBV). Two independent ebv-miRNAs are known. The ebv-miRBHRF1 family is located within the introns of BHRF1, and the ebv-miR-BART family is located in the introns of the BamHI-A region rightward transcript (BART) in two separate clusters. ${ }^{32,33}$ Viral miRNAs can maintain viral latency, evade host immune response and inhibit lytic cycle reactivation. ${ }^{34-36}$

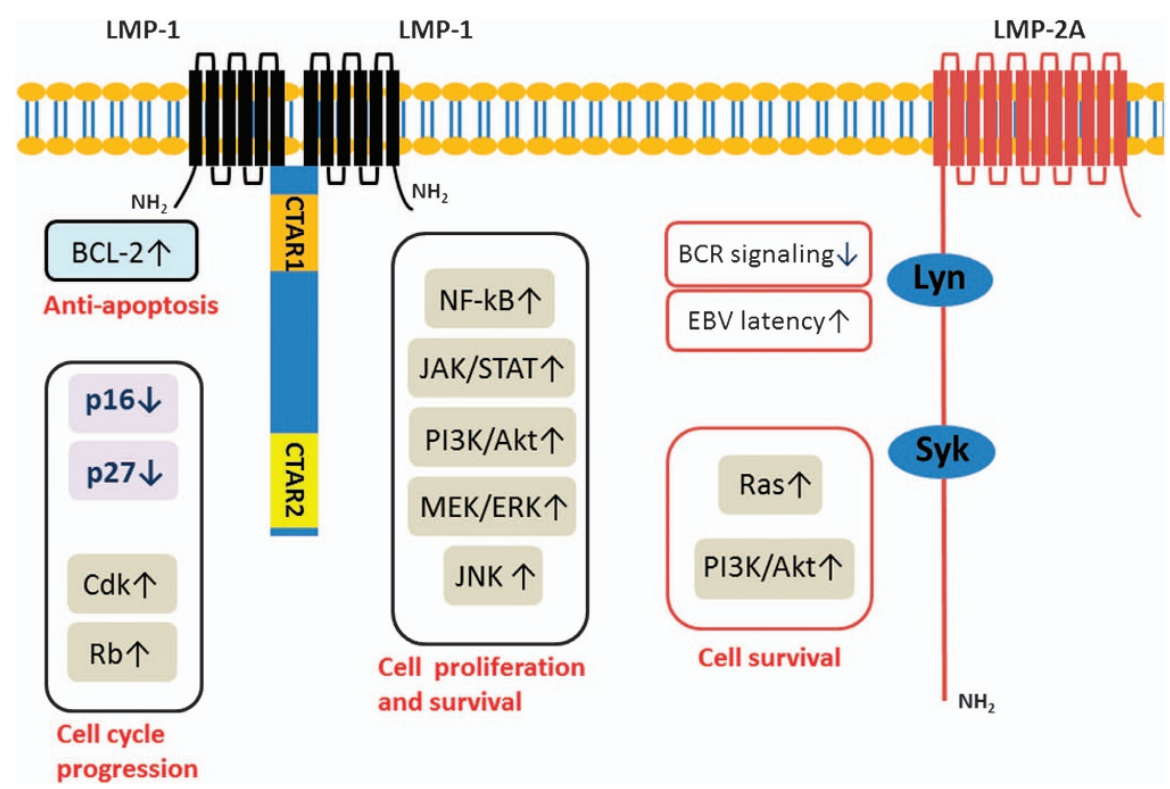

Figure 1 LMP-1 and LMP-2 and downstream signal transduction. 
A recent study has shown that multiple cellular pathways, including p53 feedback loop, B-cell signaling, oxidative stress response and apoptosis pathways, could potentially be targeted by ebv-miRNAs. ${ }^{37}$ More specifically, ebv-miR-BHRF1 can promote cell cycle progression/proliferation and prevent apoptosis. ${ }^{38}$ ebv-miR-BART5 degrades a pro-apoptotic protein and p53-upregulated modulator of apoptosis. ${ }^{39}$ Cellular miRNAs can be dysregulated by EBV latent proteins. Mir-34a and mir-155 can be induced by LMP-1 through the NF-kB pathway. ${ }^{40,41}$ EBNA-2 can enhance the NF- $\mathrm{KB}$ and Akt pathways by inducing miR-146a and downregulating miR-21, respectively. ${ }^{42}$

\section{DIAGNOSIS, DIFFERENTIAL DIAGNOSIS AND CLASSIFICATION OF EBV ${ }^{+}$LYMPHOPROLIFERATIVE DISORDERS}

\section{Benign disorders}

Infectious mononucleosis (IM) lymphadenitis. IM lymphadenitis is an acute, self-limited lymphadenitis caused by EBV infection. In the United States, most young adults are exposed to EBV, and about half of them acquire IM. Patients generally have fever, pharyngitis, lymphadenopathy and splenomegaly. Complications are rare, but splenic rupture, upper airway obstruction, severe hematologic cytopenia or hepatitis can occur. Although complications happen, these symptoms can be resolved without sequelae. Results for the agglutinationbased monospot test using horse erythrocytes are positive. EBV-specific antibodies such as IgM and IgG anti-viral capsid antigen antibodies or anti-EA antibodies appear, and circulating lymphocytes with abundant pale blue cytoplasm and large nucleus are increased. The lymph node architecture is partially effaced by paracortical hyperplasia, follicular hyperplasia or sinus histiocytosis. Paracortical expansion is the most common pattern, usually composed of a mixture of small lymphocytes, immunoblasts, plasma cells and histiocytes. Immunoblasts can form a sheet, mimicking diffuse large B-cell lymphoma (DLBCL) (Figure 2). By immunohistochemistry, CD20 highlights B-cell-rich follicles and B-immunoblasts in the paracortex. CD3 shows T-cells, mature lymphocytes and T-immunoblasts in the paracortex. In situ hybridization for EBER shows numerous EBV-infected cells. Ig genes and/or T-cell receptor genes show a polyclonal pattern.

EBV-positive mucocutaneous ulcer. EBV-positive mucocutaneous ulcer is a unique clinicopathological entity, first described by Dojcinov et al., ${ }^{43}$ who reported it in 26 patients either with immunosuppression caused by azathioprine, methotrexate or cyclosporine A given for various autoimmune diseases or with age-related immunosenescence. The median patient age was 77 years (range 24-101 years), with a slight female predominance. Interestingly, all immunosuppressed patients who had available outcome data achieved complete remission when immunosuppressants were reduced. Patients with age-related immunosenescence showed spontaneous remission or relapsing and remitting clinical course when no therapy was given. All patients with age-related immunosenescence who underwent chemotherapy and/or radiotherapy achieved complete remission. Most importantly, none of the reported patients died of the disease irrespective of treatment.

Table 1 Epstein-Barr virus latency in selected EBV-driven lymphoproliferative disorders

\begin{tabular}{lll}
\hline Latency & Gene products & Disease \\
\hline I & EBER, EBNA-1 & BL, PBL, PEL \\
II & EBER, EBNA-1, LMP-1, LMP-2A, LMP-2B & CHL, EBV+ DLBCL of the elderly, PBL (subset), LyG (subset), PTLD (subset) \\
III & EBER, EBNA-1, LMP-1, LMP-2A, LMP-2B, EBNA-2, & IM, DLBCL with CI, LyG, PTLD, EBV+ DLBCL of the elderly (subset) \\
& EBNA-3A, EBNA-3B, EBNA-3C & \\
\hline
\end{tabular}

Abbreviations: BL, Burkitt lymphoma; CHL, classical Hodgkin lymphoma; DLBCL, diffuse large B-cell lymphoma; DLBCL with CI, diffuse large B-cell lymphoma associated with chronic inflammation; EBER, Epstein-Barr virus encoded small RNA; EBNA, Epstein-Barr virus nuclear antigen; IM, infectious mononucleosis; LMP, latent membrane protein; LyG, Iymphomatoid granulomatosis; PBL, plasmablastic lymphoma; PEL, primary effusion Iymphoma; PTLD, posttransplant lymphoproliferative disorder.
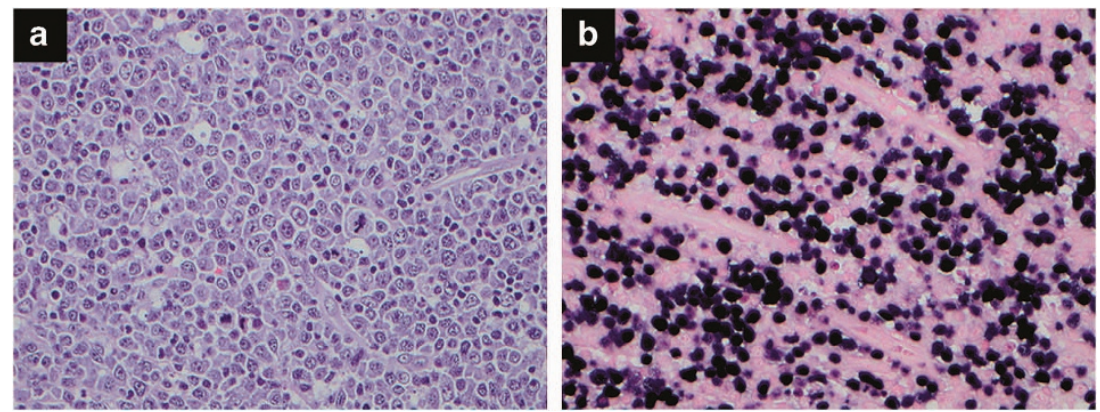

Figure 2 Infectious mononucleosis. (a) The paracortex of a lymph node is expanded by proliferation of immunoblasts. Hematoxylin and eosin, $\times 400$. (b) In situ hybridization for EBER shows numerous positive cells, $\times 400$. 
This disorder occurs as isolated, well-demarcated ulcers in the oropharyngeal mucosa, skin and gastrointestinal tract. This lesion is characterized by a polymorphous infiltrate composed of lymphocytes, immunoblasts, plasma cells, histiocytes and eosinophils with atypical large B-cell blasts resembling Hodgkin Reed-Sternberg (HRS) cells. Plasmacytoid apoptotic cells were consistently observed in all cases, and angioinvasion was not uncommonly seen (23\%). Immunohistochemistry shows a mixture of B- and T-cells in the polymorphic infiltrates. The HRS-like cells were of B-cell origin $\left(\mathrm{CD} 20^{+}, \mathrm{CD} \mathrm{a}^{+}, \mathrm{PAX}^{+}\right.$, Oct- $2^{+}$and Bob. $1^{+}$) with CD30 and CD45 expression in most cases. The intermixed T-cells were predominantly CD4-positive helper T-cells. In situ hybridization for EBER was positive in all cases, which accentuates demarcation of the lesion from the surrounding tissue. The EBER-positive cells co-expressed CD20 and PAX-5, showing the B-cell nature. Most cases showed at least phase II EBV latent infection with LMP-1 expression. Because of the presence of immunoblasts and HRS-like cells, classical Hodgkin lymphoma (CHL) or DLBCL can be misdiagnosed. Clonality tests might not help in distinguishing EBV-positive mucocutaneous ulcer from DLBCL or from T-cell lymphoma, because about $40 \%$ of cases showed clonal Ig gene rearrangement and T-cell receptor gene rearrangement, respectively.

\section{Gray disorders}

Chronic active EBV (CAEBV) disease, B-cell type. CAEBV disease is an uncommon EBV-associated lymphoproliferative disorder affecting B-cells, T-cells or NK cells. It is currently defined as a severe progressive illness of $>6$ months that begins as a primary EBV infection or is associated with heavily elevated anti-EBV viral capsid antigen IgG $\geqslant 1: 5120$ or antiEBV early antigen IgG $\geqslant 1: 640$ or markedly elevated EBV DNA in the peripheral blood with histological evidence (lymphocytic infiltration) of major organ involvement and increased EBER or proteins in the affected tissues in patients without an immunosuppressive condition. ${ }^{44}$ It was first described by Straus as 'the chronic mononucleosis syndrome' to differentiate this disease from chronic fatigue syndrome. ${ }^{45}$ The major organ involvement denotes lymphadenitis, persistent hepatitis, splenomegaly, interstitial pneumonia, hypoplasia of the bone marrow or uveitis. The etiology of CAEBV is uncertain. ${ }^{46}$ EBV stimulates secretion of a variety of cytokines and chemokines in both EBV-infected cells and non-infected cells. The current recommendation is to specify the nature of the EBV-infected cells as being B-cells, T-cells or NK cells. In this review, we focus only on CAEBV, B-cell type. For T-cell or NK cell types, please consult the article by Kimura et al. ${ }^{47}$

Most cases of CAEBV have been reported in Asia, and almost all of the Asian cases have been of T-cell or NK cell origin. ${ }^{47}$ Unlike for Asian CAEBV, the most common type $(57.9 \%)$ of CAEBV in United States is of B-cell origin. ${ }^{44}$ Of the 11 reported cases, 7 were men and 4 were women, with a median age at onset of 20 years (range $5-51$ years). The ethnic distribution was eight white patients, one black, one Hispanic and one Asian. The most common signs and symptoms were lymphadenopathy (100\%), followed by splenomegaly $(72.7 \%)$, hypogammaglobulinemia $(54.5 \%)$, fever and hemophagocytosis $(45.5 \%)$, hepatitis $(36.4 \%)$, hepatomegaly, central nervous system disease, peripheral neuropathy, interstitial pneumonia and pancytopenia (27.3\%). Histological findings of CAEBV were not characteristic. Instead, prominent $\mathrm{T}$-cell infiltrates and fewer numbers of $\mathrm{EBER}^{+}$and $\mathrm{CD}^{+} 0^{+}$lymphocytes were seen in the affected tissues. Clonal rearrangements of the IgH genes were found in five $(62.5 \%)$ of the eight tested cases. AntiEBV viral capsid antigen IgG titer was elevated $(\geqslant 1: 5120)$ in $50 \%$ of the 10 tested cases. More than half (56\%) of the patients had decreased number of $\mathrm{CD}_{1} 9^{+} \mathrm{B}$-cells compared with healthy individuals. Cytokine levels of interleukin-6, interleukin-10, tumor necrosis factor- $\alpha$, and interferon- $\gamma$ were significantly elevated in CAEBV patients compared with control patients. The 5-year overall survival rate for patients with B-cell CAEBV was 73 , but $64 \%$ of the patients eventually died.

HHV8- and EBV-associated germinotropic lymphoproliferative disorder. HHV8- and EBV-associated germinotropic lymphoproliferative disorder is a very rare disease that was first described by $\mathrm{Du}$ et al., ${ }^{48}$ reporting three patients. HHV8 latency-associated nuclear antigen (LANA) encoded by viral ORF 73 and EBER are defining features of this lesion, but the pathogenetic role of these viruses has not been fully investigated. Histologically, lymph node architecture is partially effaced with nodular proliferation of plasmablasts or bizarre anaplastic cells. The plasmablasts are not found in the mantle zone or the interfollicular area. The typical immunophenotype is $\mathrm{CD} 10^{-}, \mathrm{CD} 20^{-}, \mathrm{CD} 30^{+/-}, \mathrm{CD} 38^{+/-}, \mathrm{CD}_{99}{ }^{-}, \mathrm{CD} 138^{-}$, $\mathrm{BCL}^{-}, \mathrm{BCL}^{-}, \mathrm{MUM}^{+}, \mathrm{HHV}^{+}$and $\mathrm{EBER}^{+}$. Expression of a monotypic Ig light chain indicates a B-cell origin of the disease. This lesion shows a polyclonal or oligoclonal pattern of Ig gene rearrangement and hence is considered a lymphoproliferative disorder and not a lymphoma. Although it shows favorable outcome after chemotherapy or radiotherapy, there is little information available to fully characterize its clinical behavior.

\section{Malignant disorders}

Diffuse large B-cell lymphoma. EBV-positive DLBCL of the elderly. EBV-positive DLBCL of the elderly is defined as an EBV-positive monoclonal large B-cell lymphoproliferative disorder in immunocompetent patients aged > 50 years. ${ }^{49}$ Cases of lymphomatoid granulomatosis (LyG), plasmablastic lymphoma (PBL), primary effusion lymphoma, DLBCL associated with chronic inflammation or IM are excluded. Table 2 summarizes the morphological, immunophenotypical and genetic findings in the major $\mathrm{EBV}^{+}$lymphoid malignancies. The EBV-positive DLBCL of the elderly was originally described by Oyama et al. ${ }^{50}$ in 2003, emphasizing similarity to immunodeficiency-related lymphoproliferative disorder in immunocompetent elderly patients. An imbalanced immune system due to aging is postulated to promote lymphomagenesis. Of note, EBV positivity is generally determined to indicate positive expression of EBER in lymphoma cells, but a 
consensus for its cutoff has not been established (Figure 3) ${ }^{51}$ It is more common in Asian countries (8-11\%) than in the Western hemisphere (2-4\%), with variable EBER cutoffs. ${ }^{52-57}$ Median patient age is 71 years (range 50-91 years), with a male to female ratio of 1.4 to 1 . Epidemiological differences are seen in different geographic pockets. For example, EBV-positive DLBCL is more commonly reported in East Asia compared with Western countries. Mexican patients tend to be younger, to mostly have nodal involvement and to be less likely to express EBNA-2. ${ }^{53}$
World Health Organization (WHO) recognizes two main morphological subtypes, polymorphous and large-cell lymphoma (monomorphic). The polymorphous subtype demonstrates a range of B-cell maturation with a variable component of reactive elements. The monomorphic subtype shows a monotonous sheet of large transformed B-cells. Recently, Montes-Moreno et al..$^{58}$ subdivided the polymorphous subtype into three further subgroups. However, morphological distinction does not indicate prognostic importance. The lymphoma cells express B-cell markers. CD30 is expressed in about $40 \%$ of

Table 2 Morphologic, immunophenotypic and genetic findings helpful for differential diagnoses

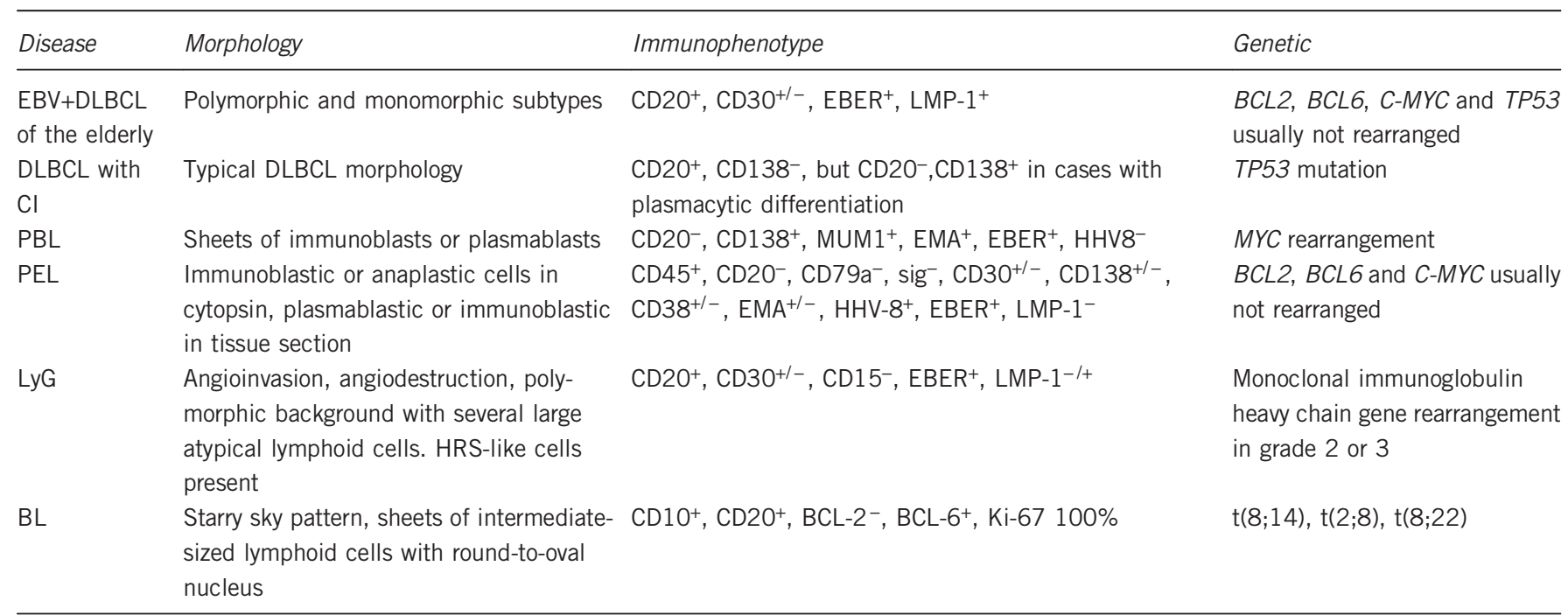

Abbreviations: BCL, B-cell lymphoma; BL, Burkitt lymphoma; DLBCL, diffuse large B-cell lymphoma; DLBCL with $\mathrm{Cl}$, diffuse large B-cell lymphoma associated with chronic inflammation; EBER, Epstein-Barr virus encoded small RNA; EMA, epithelial membrane antigen; HHV8, human herpesvirus 8; LMP, latent membrane protein; LyG, Iymphomatoid granulomatosis; MUM1, multiple myeloma oncogene 1; PBL, plasmablastic lymphoma; PEL, primary effusion lymphoma.
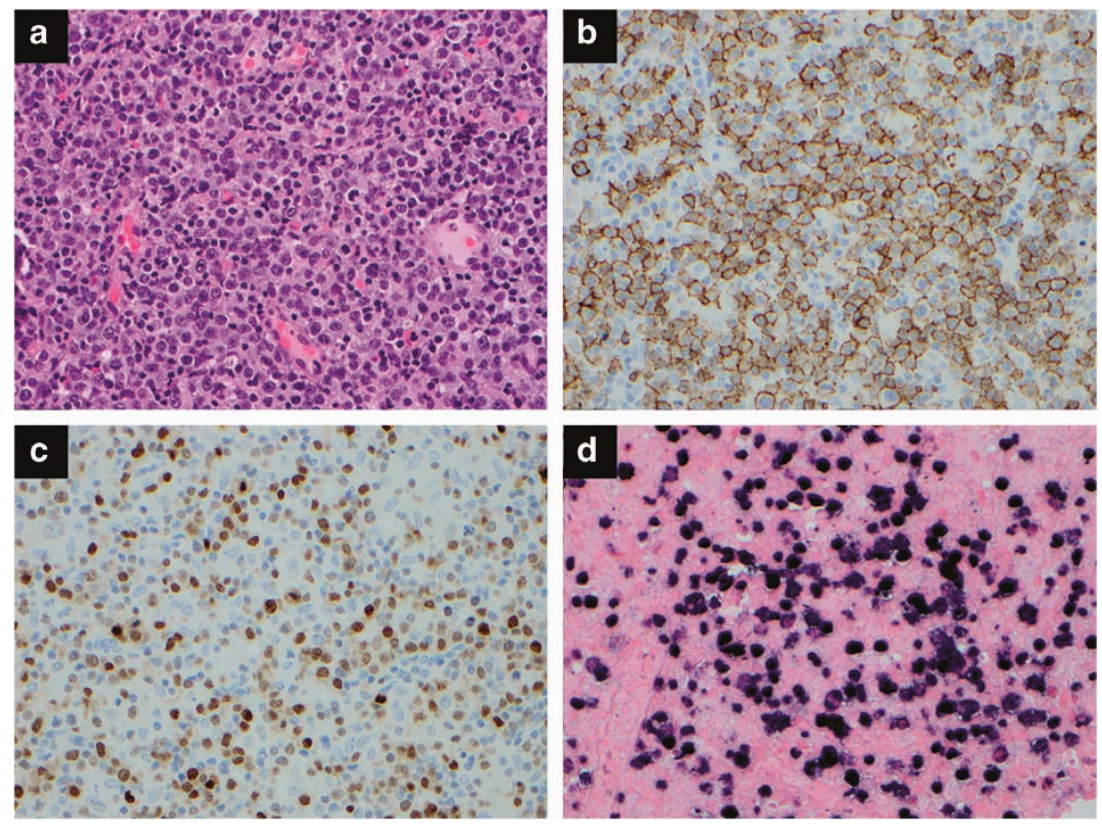

Figure 3 EBV-positive diffuse large B-cell lymphoma of the elderly. (a) The lymph node is completely effaced by a homogeneous population of large lymphoma cells. Hematoxylin and eosin, $\times 400$. (b) CD20 stain shows numerous positive B-cells, $\times 400$. (c) Ki-67 stain shows a high proliferation index, $\times 400$. (d) In situ hybridization for EBER shows positive lymphoma cells, $\times 400$. 
cases. Expression levels of NF- $\mathrm{\kappa B}$ component p50 and phosphorylated signal transducer and activator of transcription 3 (pSTAT3) are more commonly seen compared with EBVnegative DLBCL. LMP-1 and EBNA-2 are expressed in $>2 / 3$ and about $1 / 3$ of cases, respectively, hence phase II or III latency patterns. Gene expression profiling showed that EBVpositive DLBCL is molecularly distinct from EBV-negative DLBCL. The gene set enrichment assay demonstrated an enhanced Toll-like receptor signaling pathway (which has many similarities to the NF- $\mathrm{KB}$ pathway) and the Janus kinase(JAK)-STAT pathway. ${ }^{52}$ Clonal rearrangement of the Ig gene is seen in most cases. Contrary to prior reports, mostly from Asian countries, of EBV-positive DLBCL with worse prognosis, a large cohort study from Western countries did not show adverse outcome in DLBCL with single expression of EBER. However, patients with co-expression of CD30 and EBER had a worse prognosis. ${ }^{52}$ Current treatment recommendation for DLBCL does not change for EBV positivity. EBVpositive DLBCL patients respond poorly and show variations to standard R-CHOP regimen with regard to ethnic background, CD30 expression, geographical distribution and oncogenic signaling activation. Adoptive immunotherapy against EBV latency antigens and implementation of oncogenic signaling target inhibitors targeting CD30, Btk or NF-kB components may improve outcome.

DLBCL associated with chronic inflammation. DLBCL with chronic inflammation is a B-cell neoplasm, mostly associated with EBV infection, arising in patients with a long-standing chronic inflammation, such as pyothorax, chronic osteomyelitis, metallic implant or chronic skin ulcer. ${ }^{59}$ The prototype of this lymphoma is pyothorax-associated lymphoma, first described in the English literature in 1987 by Iuchi et al. ${ }^{60}$ who reported three cases during the period from 1971 to 1985. In an expanded series of 106 patients with pyothoraxassociated lymphoma by the same study group, 93 (88\%) cases were DLBCL, four cases $(4 \%)$ were lymphoplasmacytic lymphoma and four cases (4\%) were peripheral T-cell lymphoma. The immunophenotype could not be determined in five cases (4\%). ${ }^{61}$ In this series, $80 \%$ of the patients had pyothorax resulting from artificial pneumothorax for the treatment of pulmonary tuberculosis, $17 \%$ had tuberculous pleuritis and 3\% had pyothorax not associated with tuberculosis. Median age was 64 years (range $46-82$ years), with a male-to-female ratio of 12.3:1. The median latency of developing DLBCL with chronic inflammation after pyothorax was 37 years (range 20-64 years). Common symptoms were chest or back pain, fever, tumor or swelling of chest wall, and respiratory symptoms such as productive cough with or without hemoptysis and dyspnea. The tumor is mostly confined to the pleura with invasion to the adjacent tissue, such as lung, diaphragm, ribs and mediastinum. Metastasis is uncommon. About half of the cases have large $(>10 \mathrm{~cm})$ tumor. Most cases are of lower (I/II) stage. Peripheral blood and bone marrow are usually spared.

Morphology is typical for DLBCL. The abutting pleural tissue shows extensive fibrous thickening with sparse inflammatory cells, including lymphocytes and plasma cells. Most lymphoma cells are positive for CD20 and CD79a but can be negative in cases with plasmacytic differentiation. MUM-1 and CD138 are positive in such cases. EBER and EBNA-2 are positive in most cases, illustrating a type III latency program. ${ }^{61,62}$ Clonal rearrangement of the Ig gene is seen in most cases. Comparative genomic hybridization on pyothoraxassociated lymphoma tumor samples demonstrated gain of chromosome 8q24, and MYC amplification was found by Southern blotting technique. ${ }^{63}$ Sequencing of the TP53 gene (exons 5-8) using paraffin-embedded tissue found mutations in $2 / 3$ of cases, with most being single-nucleotide substitution. ${ }^{64}$ By gene expression profiling, pyothoraxassociated lymphoma was shown to be molecularly different from nodal DLBCL, with increased expression of activated B-cell-like signature. ${ }^{65}$ DLBCL with chronic inflammation is an aggressive lymphoma, with 1-, 3- and 5-year survival rates of 49,27 and $22 \%$, respectively. ${ }^{61}$

Plasmablastic lymphoma. PBL is an aggressive lymphoma with immunoblastic morphology but with plasmacytic immunophenotype. ${ }^{66}$ PBL was first described in 1997 by Delecluse et al., ${ }^{67}$ who reported 16 cases mostly in HIVpositive patients. Since the initial description of exclusive occurrence in the oral cavity, PBL has been reported in the gastrointestinal tract, soft tissue, bone, gonads, mediastinum, anal canal and nasal/paranasal area. ${ }^{68} \mathrm{PBL}$ was reported in
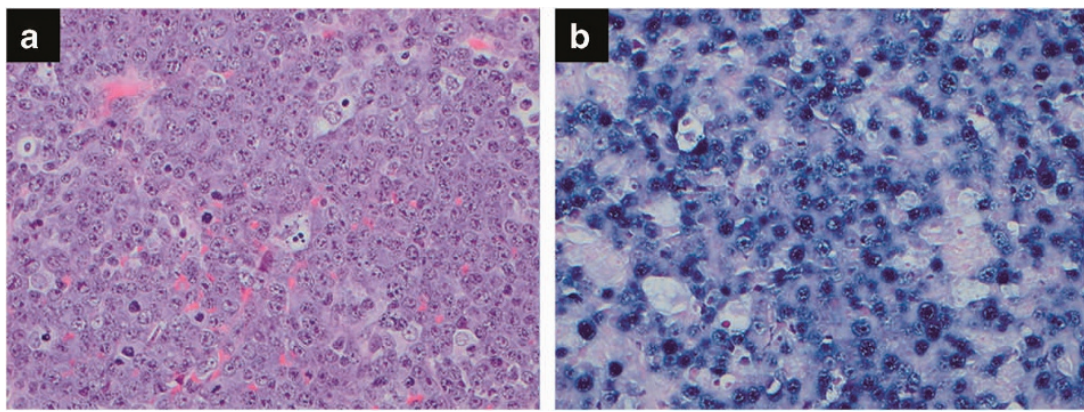

Figure 4 Plasmablastic lymphoma. (a) Sheets of immunoblasts and/or plasmablasts are present with occasional tingible-body macrophages, imparting a 'starry-sky' pattern. Hematoxylin and eosin, $\times 400$. (b) In situ hybridization for EBER shows numerous positive cells, $\times 400$. 
patients without HIV infection or immunosuppression with common nodal involvement. ${ }^{69,70}$ Median patient age is about 50 years (range 7-65 years), with a strong male predilection (7:1). Most patients are at advanced stage (stage III/IV) and with intermediate or high International Prognostic Index.

The lymphoma cells typically are of large size with round-tooval centrally or eccentrically located nucleus, dispersed chromatin, prominent single nucleolus and amphophilic cytoplasm with perinuclear hof (Figure 4). Apoptotic cells with accompanying tingible-body macrophages can be seen, imparting a starry-sky pattern at low magnification. Mitotic figures are frequently seen, consistent with a high $\mathrm{Ki}-67$ proliferation index $(90-100 \%)$. The lymphoma cells mostly express plasmacytic markers such as CD38 (100\%), MUM1 (100\%) and CD138 (84\%). CD79a is uncommonly expressed (14\%); CD20 is virtually not expressed (3\%). CD45 expression is seen in $1 / 3$ of the cases. Frequent $(80 \%)$ expression of epithelial membrane antigen is observed. HHV8 LANA is negative, which is very helpful for differentiating PBL from morphologically similar large B-cell lymphoma arising in HHV8-associated multicentric Castleman disease. ${ }^{71}$ Most PBLs are positive for EBER (78\%), but with less frequent LMP-1 expression (38\%). Hence, the latency pattern is either phase I or II. By FISH, MYC rearrangement was seen, with about $50 \%$ having $\operatorname{IgH}$ as the most common partner. ${ }^{72}$ Of note, $M Y C$ rearrangement was more commonly seen in EBER-positive PBL compared with EBER-negative PBL. Clonal rearrangement of Ig gene is seen in most cases. No effective treatment exists for PBL and patients often have a high stage at diagnosis and harbor a poor survival.

Primary effusion lymphoma. Primary effusion lymphoma $(\mathrm{PEL})$ is a rare B-cell neoplasm presenting as a lymphomatous effusion in pleural, pericardial, or peritoneal cavities without detectable tumor mass, usually in immunosuppressant patients. ${ }^{73}$ The term PEL was first proposed by Nador et al. in 1996 and recognized by WHO in 2001 as a distinct clinicopathologic entity, although it had been recognized as a body cavity-based lymphoma. ${ }^{74}$ It is almost always associated with HHV8 and very commonly associated with EBV. Lymphoma with the same immunophenotype presenting as a solid tumor mass without malignant effusion is regarded as a variant of this entity and is called extracavitary PEL. ${ }^{75}$

Most patients are young or middle-aged homosexual men with HIV infection. PEL can arise in posttransplant patients without HIV infection or rarely in non-immunosuppressant patients. ${ }^{76,77}$ HHV8 is believed pathogenetically to be more important than EBV in PEL, because HHV8 expresses oncogenic cellular homologues with a restricted pattern of EBV infection (mostly phase I) ${ }^{78,79}$ Typical clinical presentation is effusion in a single body cavity without lymphadenopathy or organomegaly. Kaposi sarcoma precedes PEL in about half of the patients. Extracavitary PEL has been reported in lymph nodes and various extranodal locations, most commonly in the gastrointestinal tract. ${ }^{80}$

In cytospin samples, the lymphoma cells show a morphological range from immunoblastic to anaplastic features. Variable numbers of large pleomorphic cells are seen, some of which resemble Reed-Sternberg cells. A prominent Golgi zone adjacent to the nucleus is often present in the lymphoma cells. In tissue sections, the lymphoma cells have round or ovoid to polygonal shape, moderate-to-large amounts of cytoplasm and round to variably indented nuclei with one or more prominent nucleoli (Figure 5). Multinucleated giant
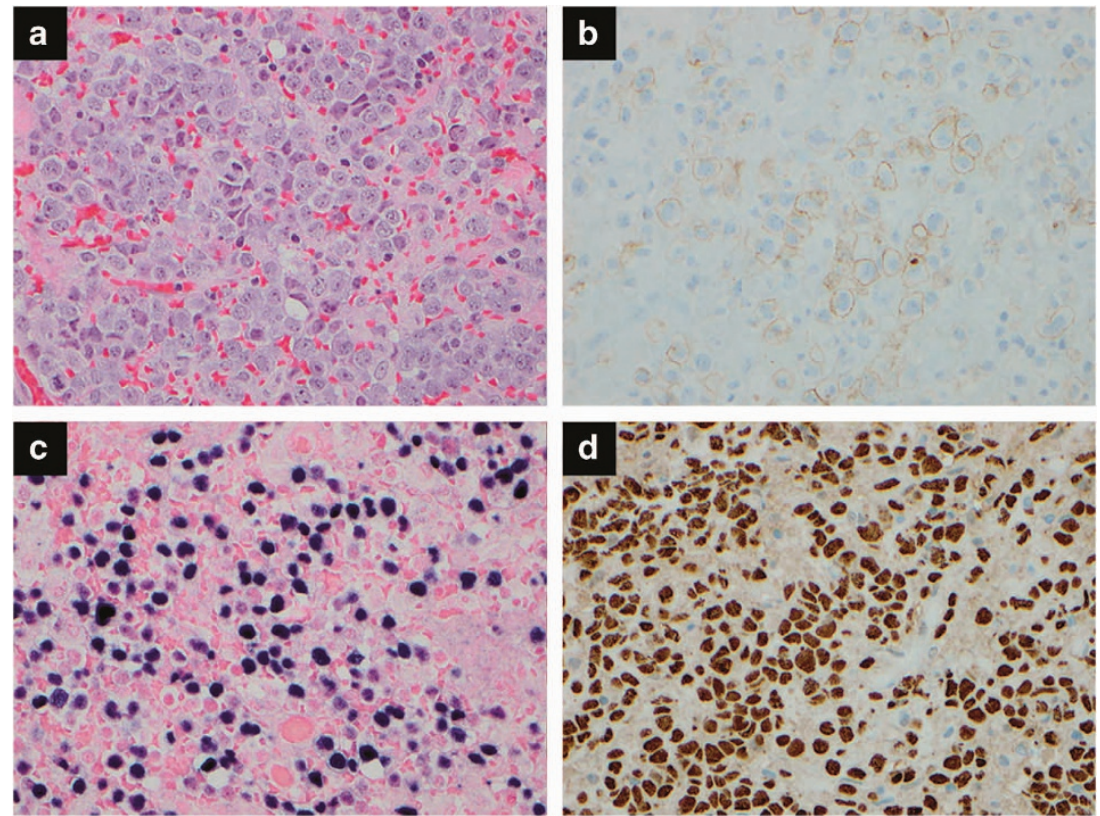

Figure 5 Extracavitary pleural effusion lymphoma. (a) Sheets of immunoblasts and/or plasmablasts are present with frequent mitotic figures. Hematoxylin and eosin, $\times 400$. (b) CD138 stain is positive in most of the lymphoma cells, $\times 400$. (c) In situ hybridization for EBER shows many positive cells, $\times 400$. (d) HHV-8 stain is positive in the lymphoma cells, $\times 400$. 
tumor cells and lymphoma cells with wreath-like nuclei, resembling hallmark cells in anaplastic large cell lymphoma, can be seen. Mitotic figures are numerous. The lymphoma cells usually express CD45 without expression of pan-B markers (CD19, CD20, CD22 and CD79a) or T/NK cell markers. Surface and cytoplasmic Igs are generally absent. CD30, epithelial membrane antigen, CD38, CD138 and HLA-DR are variably positive. LANA-1 of HHV8 is typically positive with a nuclear dot-like pattern. EBER is positive in about $70 \%$ of cases, but LMP-1 is negative. Extracavitary PEL shares a similar immunophenotype but with more common expression of B-cell markers.

Recurrent cytogenetic abnormalities have not been reported. Comparative genomic hybridization of eight PEL cases showed gain of chromosomes 12 and $\mathrm{X}$ in three and two cases, respectively, and amplification within the 1q region in two cases. ${ }^{81}$ BCL-2, BCL-6 and MYC genes were not rearranged, and mutations in MYC, HRAS, KRAS, NRAS and TP53 genes were not found. ${ }^{74}$ Clonal rearrangement of the Ig gene is seen in most cases and can be used for determining lineage. Gene expression profiling showed that PEL is distinct from nonHodgkin lymphomas in immunocompetent patients and from AIDS-related lymphomas. The study also showed that PEL is in the differentiation stage of plasmablasts, because the gene expression profile showed features of immunoblasts, between EBV-transformed lymphoblastoid cell lines or AIDS immunoblastic lymphoma and plasma cells from multiple myeloma cell lines. ${ }^{82}$ Effective treatment lacks in PEL, and patients often demonstrate a dismal outcome.

Lymphomatoid granulomatosis. LyG was first reported by Liebow et al. ${ }^{83}$ in 1972 as nodular and granulomatous lesions. It is a rare EBV-driven angiocentric and angiodestructive lymphoproliferative disorder with a spectrum of clinical manifestation depending on the number of EBER-positive abnormal cells. ${ }^{84}$ It usually affects adults, typically in the fourth to sixth decade of life, with a male predominance (male-tofemale ratio $>2: 1$ ). Patients with congenital immunodeficiency, immunosuppressed patients or those with autoimmune disease are at increased risk. It is generally an extranodal disease. Lung involvement is almost always present, followed by kidney, skin and central nervous system. Lymph node and spleen are usually not involved at the initial presentation but can be involved when the disease has progressed. Lung involvement is usually bilateral, and middle/lower lobes are preferred sites. Clinically, it can present with fever, productive cough and dyspnea, mimicking infection. Other symptoms include malaise, weight loss, fatigue, variable neurological symptoms and gastrointestinal symptoms.

Histologically, LyG is characterized by a small number of EBER-positive intermediate-to-large atypical B-cells in a background of T-lymphocytes, plasma cells and histiocytes. Angioinvasion and angiodestruction are commonly seen. Although the name implies granulomatous reaction, wellformed granulomas are generally absent. Poorly formed granulomas can be seen in subcutaneous tissue. ${ }^{85}$ EBER- positive B cells have immunoblastic or pleomorphic morphology, resembling mononuclear Hodgkin cells. However, classic binuclear Reed-Sternberg cells are not present. The EBERpositive atypical B-cells are positive for $\mathrm{CD} 20$, with variable expression of CD30, but negative for CD15. CD4-positive $\mathrm{T}$-cells are more predominant than CD8-positive T-cells in the background. Available data regarding latent EBV infection pattern in LyG showed latency II or III in most cases. ${ }^{86}$

LyG can be graded based on the number of EBER-positive atypical B-cells. Grade 1 LyG typically has only a few EBERpositive atypical B-cells ( $<5$ per high-power field), and they might be absent in some cases. Grade 2 LyG typically has 5-20 EBER-positive atypical B-cells per high-power field, and grade 3 LyG usually has $>50$. Grade 3 LyG is usually regarded as a DLBCL equivalent because of its aggressive clinical behavior and therapeutic options similar to those for DLBCL. On the other hand, grade 1 and 2 LyG usually have an indolent course. However, one should be aware that about $15 \%$ of lower grade LyG can progress to malignant lymphoma. ${ }^{87}$ PCR analysis for Ig heavy chain gene rearrangement demonstrated a monoclonal pattern. ${ }^{88}$ Grade III LyG patients are treated with similar regimens used for DLBCL and DA-EPOCH-R has been reported to be effective with $66 \%$ complete remission. Interferon- $\alpha$ was reported to be effective in nearly $60 \%$ grade I and II LyG patients; however, a high frequency of recurrence is noted.

Burkitt lymphoma. BL is a germinal center-derived aggressive B-cell lymphoma with frequent MYC translocation. It was first described by Dr Dennis Burkitt in 1958 in Kampala, Uganda, as a common pediatric tumor involving the jaw. ${ }^{89} \mathrm{WHO}$ currently recognizes three different clinical variants based on geographical information and HIV status. ${ }^{90}$ Endemic BL occurs in equatorial Africa and usually affects 4-7-year-old children, with a male predominance (2:1). Facial bones, especially jaw bones, are usually involved. Its geographical distribution overlaps with that of malaria infection..$^{91}$ However, the role of malaria in the pathogenesis of BL is still unclear. Sporadic BL occurs worldwide, with a low incidence (1-2\%) of all lymphomas. Young adults are usually affected, with a male: female ratio of 2-3:1. The ileocecal region is the most commonly affected site, followed by ovaries, kidneys and breasts. Immunodeficiency-associated BL specifically occurs in patients with HIV infection, congenital immunodeficiencies or posttransplantation status. All variants have a high tendency for central nervous system involvement. In endemic BL, EBV is detected in the majority of cases. However, EBV is seen in about 30\% of sporadic and immunodeficiency-associated BL.

Endemic and sporadic BL typically shows a diffuse proliferation of intermediate-sized lymphoma cells, which have roundto-oval nucleus, dispersed chromatin, 2-3 discernible small nucleoli and squared-off borders for the cytoplasm. Numerous apoptotic cells with accompanying tingible-body macrophages are present, imparting a 'starry-sky' pattern at low magnification (Figure 6). Rare cases might show an intense granulomatous reaction. In Giemsa-stained slides, lymphoma cells have 

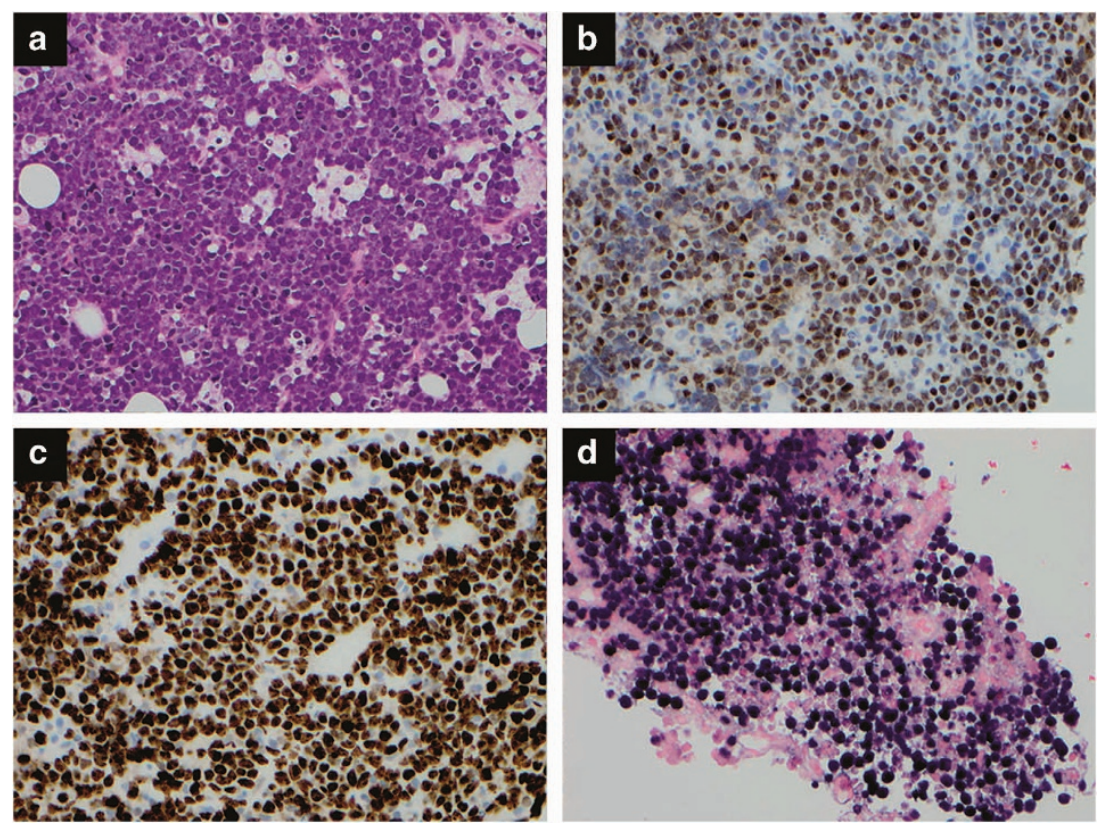

Figure 6 Burkitt lymphoma. (a) Sheets of medium-sized cells with numerous tingible-body macrophages showing the classic starry-sky pattern. Hematoxylin and eosin, $\times 400$. (b) BCL- 6 stain is positive in lymphoma cells, $\times 400$. (c) Ki-67 proliferation rate is virtually $100 \%$, $\times 400$. (d) In situ hybridization for EBER shows numerous positive cells, $\times 400$.

basophilic cytoplasm with numerous cytoplasmic vacuoles. Immunodeficiency-associated BL commonly shows plasmacytic differentiation with eccentrically located nucleus, a prominent central nucleolus and more abundant cytoplasm. The lymphoma cells express B-cell markers, CD10 and BCL-6. BCL-2 expression is negative or weak and TdT is negative. The Ki-67 proliferation index is nearly $100 \%$.

MYC rearrangement is characteristic but not a unique finding. $\mathrm{t}(8 ; 14)(\mathrm{q} 24 ; \mathrm{q} 32)$ involving the Ig heavy chain region is commonly $(80 \%)$ found, followed by $\mathrm{t}(2 ; 8)(\mathrm{p} 12 ; \mathrm{q} 24)$ and $\mathrm{t}(8 ; 22)(\mathrm{q} 24 ; \mathrm{q} 11)$ involving kappa and lambda light chain loci, respectively. Cytogenetic abnormalities other than MYC rearrangement are rare. ${ }^{92}$ Gene expression profiling revealed that $\mathrm{BL}$ closely resembles the centroblast-rich dark zone of the germinal center, whereas DLBCL with a germinal center B-celllike phenotype is similar to the centrocyte-rich light zone of the germinal center. ${ }^{93}$ miRNA analysis found that expression of miRNAs targeted by Myc protein and miRNAs associated with NF- $\mathrm{KB}$ are significantly downregulated in BL compared with DLBCL. ${ }^{94}$ This study also showed that there was no or only minimal miRNA expression differences among the three BL variants, suggesting that the variants are the same biological entity with a different spectrum. Next-generation sequencing identified a novel loss-of-function mutation in ID3. ${ }^{95-97}$ The deleterious mutations disrupt the normal function of ID3 as a tumor suppressor and promote cell cycle progression and proliferation. Next-generation sequencing also revealed mutations in MYC, TP53, DDX3X, TCF3, SMARCA4 and other genes. $\mathrm{EBV}^{+} \mathrm{BL}$ patients show no difference in outcome from $\mathrm{EBV}^{-} \mathrm{BL}$, and $\mathrm{EBV}$ positivity in $\mathrm{BL}$ does not impact prognosis and treatment regimen selection. Patients commonly receive high-intensity, short-duration combination chemotherapy regimens, such as DA-EPOCH-R with nearly $100 \%$ response rate and low adverse event.

Classical Hodgkin lymphoma. Hodgkin lymphoma was first described by Sir Thomas Hodgkin in $1832 .{ }^{98}$ Hodgkin lymphomas include nodular lymphocyte-predominant Hodgkin lymphoma and CHL. CHL is further subdivided into nodular sclerosis, mixed cellularity, lymphocyte-rich and lymphocytedepleted subtypes. CHL is characterized by the presence of scattered neoplastic HRS cells in a rich background of lymphocytes, eosinophils, plasma cells, neutrophils and histiocytes with various degrees of fibrosis. CHL has a peak of incidence in persons aged 15-35 years and a smaller second peak in an older group, aged 45-60 years. It often involves the axial lymph nodes, especially cervical nodes, and mediastinum with rare involvement of extranodal sites. CHL is usually a localized (stage I or II) disease, and the bone marrow is generally spared $(<5 \%)$, except in patients with HIV infection (approximately 50\%).

The classic Reed-Sternberg cells are large cells with two or more round nuclei, dispersed chromatin, prominent nucleolus and abundant basophilic cytoplasm with a perinuclear halo (Figure 7). The mononuclear variant is called the Hodgkin cell. HRS cells are characteristically positive for CD30, CD15, PAX-5 (weak/nuclear expression), MUM-1 and fascin but negative for CD3, CD20, CD45, CD68 (PG-M1), CD79a and CD138. EBV is seen in CHL, most commonly in mixed cellularity and lymphocyte depleted, followed by lymphocyte rich and nodular sclerosis. EBV-infected HRS cells usually express LMP-1 without EBNA-2 expression (phase II latency). ${ }^{99}$ HRS single-cell PCR showed a monoclonal Ig gene rearrangement with preservation of Ig-coding capacity, 

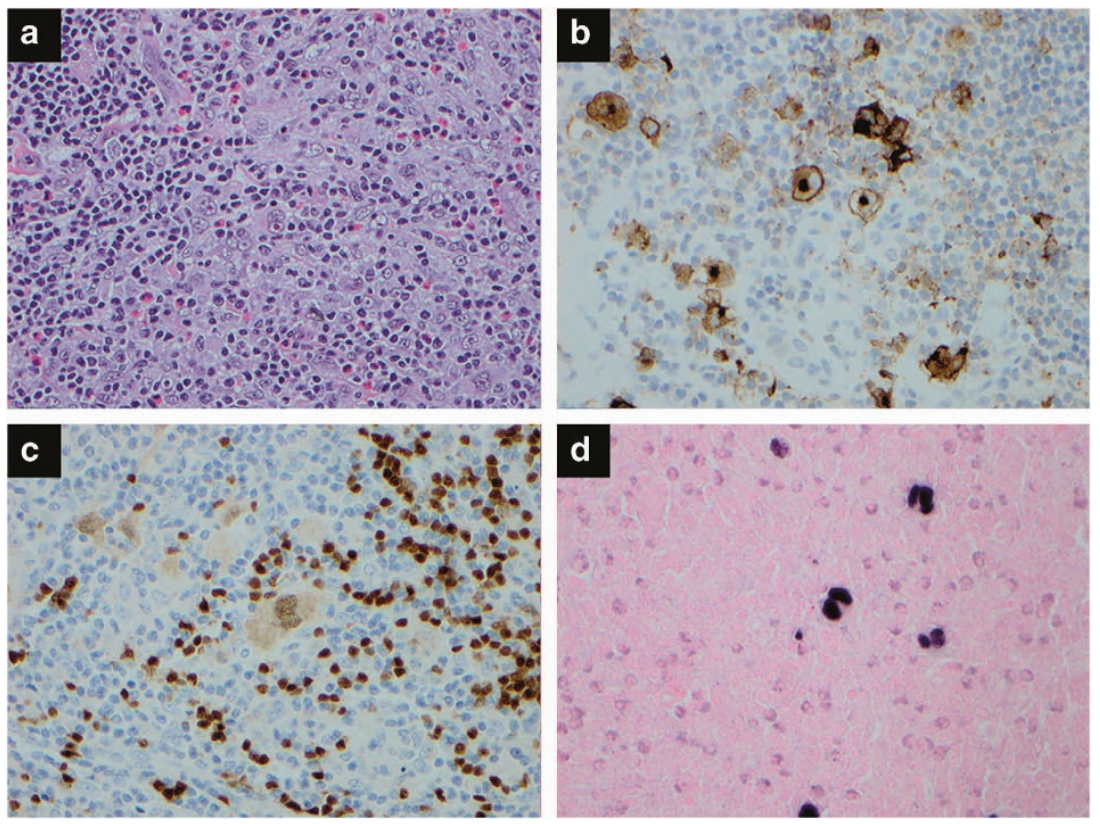

Figure 7 Classical Hodgkin lymphoma. (a) A classic binuclear Reed-Sternberg cell (center) and occasional mononuclear Hodgkin cells are intermixed with many mature-appearing lymphocytes, eosinophils, occasional plasma cells and histiocytes. Hematoxylin and eosin, $\times 400$. (b) Hodgkin Reed-Sternberg cells express CD30 with a membranous and Golgi pattern, $\times 400$. (c) A weak nuclear expression of PAX5 is seen in Hodgkin Reed-Sternberg cells. In contrast, B-lymphocytes in the background show strong expression of PAX5, $\times 400$. (d) Occasional Hodgkin Reed-Sternberg cells are positive for EBER, $\times 400$.

suggesting that the lack of B-cell markers is caused by defects in Ig gene regulatory elements. ${ }^{100}$ Array-based comparative genomic hybridization applied to microdissected HRS cells revealed frequent recurrent gains in chromosomes $2 \mathrm{p} 12-16,5 \mathrm{q} 15-23$, $6 \mathrm{p} 22,17 \mathrm{q} 12$ and $19 \mathrm{p} 13$ and losses in Xp21, 6q23-24 and $13 \mathrm{q} 22 .{ }^{101}$ Gene expression profiling of microdissected HRS cells showed downregulation of B-cell lineage genes, deregulation of transcription factor networks and upregulation of NF-KB and JAK-STAT pathway-related genes and various chemokines and cytokines. ${ }^{102}$ A miRNA signature was found with 234 differentially expressed miRNAs in CHL. ${ }^{103}$ Gene expression profiling data and miRNA data could provide additional information on risk stratification of CHL. Primary $\mathrm{EBV}^{+} \mathrm{HL}$ patients show a poor survival from $\mathrm{EBV}^{-} \mathrm{HL}$; however, EBV positivity does not impact treatment regimen selection. In recurrent $\mathrm{EBV}^{+} \mathrm{HL}$ with worse prognosis, adaptive immunotherapy, CD30 antibody and NF-kB pathway inhibitors may show therapeutic promise.

Posttransplant lymphoproliferative disorders. Posttransplant lymphoproliferative disorders (PTLD) are a heterogeneous group of diseases in immunocompromised patients who are recipients of a solid organ or hematopoietic stem cell transplant. ${ }^{104}$ PTLD shows a spectrum from indolent polyclonal proliferation to overtly malignant proliferation of lymphocytic or plasma cells. About 5\% of PTLD are T-cell type. PTLD was first described by Doak et al. ${ }^{105}$ in 1968 in two renal transplant recipients. The first year after transplantation has the highest risk. ${ }^{106}$ Up to $2 / 3$ of PTLD cases are associated with EBV. The risk of developing PTLD is higher in EBV- negative recipients than in EBV-positive ones, with the highest risk in $\mathrm{EBV}^{+}$donor/EBV ${ }^{-}$recipients. ${ }^{107}$ An increase in $\mathrm{EBV}$ viral load and a decrease of EBV-specific cytotoxic T-cells are associated with the development of PTLD. ${ }^{108}$ Recipients of solid organ transplants, especially heart, lung, intestine or multiple organs, have higher risks of PTLD compared with patients with hematopoietic stem cell transplant. PTLD involves extranodal sites, including the tonsils, gastrointestinal tract, lung and liver as well as lymph nodes.

Morphologically, PTLD can be categorized by early lesions, polymorphic PTLD, monomorphic PTLD and CHL-type PTLD. Early lesions are further subdivided into plasmacytic hyperplasia and IM-like lesions. Plasmacytic hyperplasia is characterized by an increased number of plasma cells without effacement of tissue architecture and with residual germinal centers. IM-like lesions show the typical morphology of IM as described above. Both show minimal cytological atypia. Immunophenotype and molecular studies do not usually detect monotypic/monoclonal B-cell or plasma cell populations. Polymorphic PTLD is a destructive extranodal mass or a lesion with effacement of lymph node architecture. A polymorphic population of lymphocytes, plasma cells, immunoblasts and histiocytes is typically seen, with a variable presence of HRSlike cells (Figure 8). Of note, the full range of B-cell maturation is present, which is a morphological clue in differentiating polymorphic PTLD from monomorphic PTLD. Monotypia may or may not be seen, but the Ig gene is clonally rearranged. Monomorphic PTLD is an outright lymphoma, identical to that in immunocompetent patients. Of note, follicular lymphoma and mucosa-associated lymphoid tissue lymphoma are 

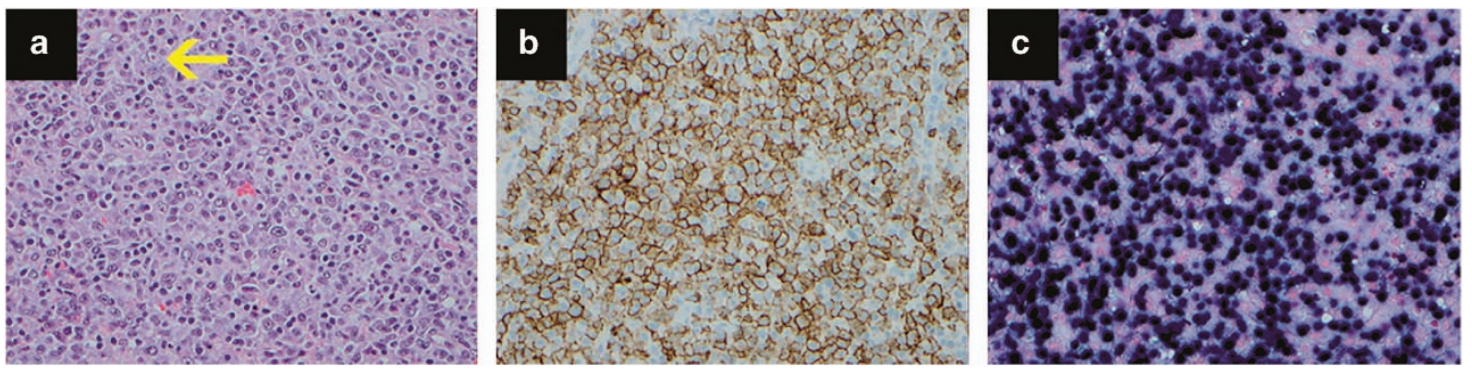

Figure 8 Posttransplant lymphoproliferative disorder, polymorphic type. (a) A mixture of immunoblasts, lymphocytes, plasma cells and Hodgkin Reed-Sternberg-like cells (arrow) is present. Hematoxylin and eosin, $\times 400$. (b) CD20 stain shows a B-cell proliferation, $\times 400$. (c) In situ hybridization for EBER shows numerous positive cells, $\times 400$.

not designated as PTLD. ${ }^{104}$ CHL-type PTLD should have classic morphology and immunophenotype and should be differentiated from polymorphic PTLD with HRS-like cells. That is, the immunophenotype for CHL-type PTLD is CD15 $\mathrm{CD} 20^{-}, \mathrm{CD} 30^{+}, \mathrm{CD} 45^{-}$and PAX5 weak $^{+}$, whereas the immunophenotype for polymorphic PTLD with HRS-like cells is usually $\mathrm{CD} 15^{-}, \mathrm{CD} 20^{+}$and $\mathrm{CD} 45^{+}$. EBER is almost always positive. These categories represent a spectrum of disease and can be difficult to separate in clinical practice.

Conventional karyotypic studies are correlated with morphological categories. Clonal karyotypes were seen $15-30 \%$ of polymorphic PTLD and $70-75 \%$ of monomorphic PTLD. ${ }^{109,110}$ Array comparative genomic hybridization detected gains at 5p13.1-p15.33 and 11p11.2-p15.5 and losses of $17 \mathrm{p} 13.2-\mathrm{p} 11.2,12 \mathrm{p} 13.31-\mathrm{p} 13.3$ and $12 \mathrm{q} 24.33$, with low frequency in monomorphic PTLD, DLBCL type. ${ }^{111}$ Gene expression profiling of PTLD showed a clear segregation between $\mathrm{EBV}^{+}$PTLD and $\mathrm{EBV}^{-}$PTLD, which had minimal differences from DLBLC in immunocompetent patients. In the former, upregulated genes were related to an innate immune response induced by interferon, NK and cytotoxic T-cell markers and tolerance. ${ }^{12}$ Data regarding epigenetics is rare, but hypermethylation of $\mathrm{O}^{6}$-methylguanine-DNA methyltransferase and death-associated protein-kinase was seen in $57 \%$ and $72 \%$ of PTLD, respectively. ${ }^{113}$ Proteomic analysis of monomorphic PTLD showed upregulated proteins in the PI3K/Akt, mitogen-activated protein kinase, protein kinase $\mathrm{C}$ and NF- $\mathrm{\kappa B}$ pathways. ${ }^{114}$ PTLD typically shows type III latency features with expression of nine EBV latency proteins (Table 2), and no optimal management approaches exist. Reduction of immunosuppression may induce durable remission in localized or indolent disease but harbor risk for the graft rejection. Variable successes are observed in aggressive type treated with combination immunochemotherapy. Immunotherapy regimens with EBV-specific cytotoxic T-lymphocytes have shown promising efficacy for prevention and treatment.

Other immunomodulator-associated lymphoproliferative disorders have been rarely reported. Similar to PTLD, iatrogenic immunodeficiency-associated lymphoproliferative disorders have been reported in patients who had been treated with purine analogue (fludarabine, pentostatin or clofarabine) with or without alemtuzumab, methotrexate, anti-tumor necrosis factor- $\alpha$ agents (infliximab, adalimumab or etanercept) or other immunomodulators (daclizumab, anakinra or efalizumab) for various lymphoproliferative disorders, leukemia or autoimmune diseases. ${ }^{115-120}$ Association with EBV was also seen in variable numbers of such cases. A broad range of clinical manifestation has been reported, ranging from regression without treatment to an aggressive course leading to patient death. Reduction or withdrawal of immunosuppression may induce durable remission in some patients.

\section{SUMMARY}

EBV is a well-known oncogenic virus and affects about $90 \%$ of the population worldwide. Once EBV infects B-lymphocytes, it achieves latent infection as an episomal form with limited expression of a few latent genes. EBV latent proteins are well known for oncogenesis, and EBV is associated with various lymphoproliferative disorders that range broadly from benign diseases to aggressive malignant neoplasms. Oncogenic role and mechanism that EBV has vary in different clinical setting, lymphoma subtype, ethnic predisposition and genomic aberration. Optimal treatment is generally lacking in most of $\mathrm{EBV}^{+}$ lymphomas; novel therapeutic approaches and associated randomized clinical trials for prevention and treatment are heavily demanded. Three latency types are associated with unique entities of lymphoma pathogenesis; type I relates to selective EBNA-1 expression in BL, PEL and PBL. Immunotherapy with EBNA-1-specific $\mathrm{CD} 4^{+}$cytotoxic T-lymphocytes is likely effective. Type II relates to the expression of EBNA-1, LMP-1 and LMP-2 in CHL and a subset of DLBCL. Cellular therapy targeting on LMP-2 may induce clinical response. Type III associates with the expression of nine EBV proteins in PTLD, IM, LyG and DLBCL. Future studies are valuable to explore novel therapeutic agents, including miRNAtargeted therapy, EBV vaccine, specific EBV signaling pathway inhibitors and combination of EBV lytic phase induction and anti-EBV drugs.

\section{ACKNOWLEDGEMENTS}

This work was supported by the Fellowship Award at the MD Anderson Cancer Center (to CYO); the Scholarship Award at the Zhengzhou University School of Medicine (to LL); and The University of Texas MD Anderson Cancer Center Institutional Research Grant 
Award, an MD Anderson Lymphoma Specialized Programs of Research Excellence (SPORE) Research Development Program Award, an MD Anderson Myeloma SPORE Research Development Program Award, MD Anderson Collaborative Research Funds with HighThroughput Molecular Diagnostics, Gilead Science, Adaptive Biotechnologies and Roche Molecular Systems (to KHY). This work was also partially supported by National Cancer Institute and National Institutes of Health grants (R01CA138688, 1RC1CA146299, P50CA136411 and P50CA142509) and by the MD Anderson Cancer Center Support grant CA016672.

1 Epstein MA, Achong BG, Barr YM. Virus particles in cultured lymphoblasts from Burkitt's lymphoma. Lancet 1964; 1: 702-703.

2 Yao QY, Rickinson AB, Epstein MA. A re-examination of the Epstein-Barr virus carrier state in healthy seropositive individuals. Int J Cancer 1985; 35: 35-42.

3 Castillo JJ, Reagan JL, Bishop KD, Apor E. Viral lymphomagenesis: from pathophysiology to the rationale for novel therapies. Br J Haematol 2014; 165: 300-315.

4 Sixbey JW, Nedrud JG, Raab-Traub N, Hanes RA, Pagano JS. Epstein-Barr virus replication in oropharyngeal epithelial cells. New Engl J Med 1984; 310: $1225-1230$.

5 Fingeroth JD, Weis JJ, Tedder TF, Strominger JL, Biro PA, Fearon DT. Epstein-Barr virus receptor of human $B$ lymphocytes is the $\mathrm{C} 3 \mathrm{~d}$ receptor CR2. Proc Natl Acad Sci USA 1984; 81: 4510-4514.

6 Li Q, Spriggs MK, Kovats S, Turk SM, Comeau MR, Nepom B et al. Epstein-Barr virus uses HLA class II as a cofactor for infection of B lymphocytes. J Virol 1997; 71: 4657-4662.

7 Given D, Yee D, Griem K, Kieff E. DNA of Epstein-Barr virus. V. Direct repeats of the ends of Epstein-Barr virus DNA. J Virol 1979; 30: 852-862.

8 Yates J, Warren N, Reisman D, Sugden B. A cis-acting element from the Epstein-Barr viral genome that permits stable replication of recombinant plasmids in latently infected cells. Proc Natl Acad Sci USA 1984; 81 3806-3810.

9 Johannsen E, Koh E, Mosialos G, Tong X, Kieff E, Grossman SR. EpsteinBarr virus nuclear protein 2 transactivation of the latent membrane protein 1 promoter is mediated by $\mathrm{J}_{\kappa}$ and PU.1. J Virol 1995; 69: 253-262.

10 Kieff ED, Rickinson AB (eds). Epstein-Barr Virus and Its Replication. Lippincott Williams and Wilkins: Philadelphia, PA, USA, 2006

11 Le Roux A, Kerdiles B, Walls D, Dedieu JF, Perricaudet M. The EpsteinBarr virus determined nuclear antigens EBNA-3A, $-3 B$, and $-3 C$ repress EBNA-2-mediated transactivation of the viral terminal protein 1 gene promoter. Virology 1994; 205: 596-602.

12 Kulwichit W, Edwards RH, Davenport EM, Baskar JF, Godfrey V, Raab-Traub N. Expression of the Epstein-Barr virus latent membrane protein 1 induces B cell lymphoma in transgenic mice. Proc Natl Acad Sci USA 1998; 95: 11963-11968.

13 Uchida J, Yasui T, Takaoka-Shichijo Y, Muraoka M, Kulwichit W, Raab-Traub $\mathrm{N}$ et al. Mimicry of CD40 signals by Epstein-Barr virus LMP1 in B lymphocyte responses. Science 1999; 286: 300-303.

14 Liebowitz D. Epstein-Barr virus and a cellular signaling pathway in lymphomas from immunosuppressed patients. New Engl J Med 1998 338: 1413-1421.

15 Henderson S, Rowe M, Gregory C, Croom-Carter D, Wang F, Longnecker R et al. Induction of bcl-2 expression by Epstein-Barr virus latent membrane protein 1 protects infected $B$ cells from programmed cell death. Cell 1991; 65: 1107-1115.

16 Fries KL, Miller WE, Raab-Traub N. Epstein-Barr virus latent membrane protein 1 blocks p53-mediated apoptosis through the induction of the A20 gene. J Virol 1996; 70: 8653-8659.

17 Dawson CW, Tramountanis G, Eliopoulos AG, Young LS. Epstein-Barr virus latent membrane protein 1 (LMP1) activates the phosphatidylinositol 3-kinase/Akt pathway to promote cell survival and induce actin filament remodeling. J Biol Chem 2003; 278: 3694-3704.

18 Roberts ML, Cooper NR. Activation of a ras-MAPK-dependent pathway by Epstein-Barr virus latent membrane protein 1 is essential for cellular transformation. Virology 1998; 240: 93-99.
19 Eliopoulos AG, Waites ER, Blake SM, Davies C, Murray P, Young LS TRAF1 is a critical regulator of JNK signaling by the TRAF-binding domain of the Epstein-Barr virus-encoded latent infection membrane protein 1 but not CD40. J Virol 2003; 77: 1316-1328.

20 Everly DN Jr, Mainou BA, Raab-Traub N. Induction of Id1 and Id3 by latent membrane protein 1 of Epstein-Barr virus and regulation of $\mathrm{p} 27 / \mathrm{Kip}$ and cyclin-dependent kinase 2 in rodent fibroblast transformation. J Virol 2004; 78: 13470-13478.

21 Laux G, Perricaudet M, Farrell PJ. A spliced Epstein-Barr virus gene expressed in immortalized lymphocytes is created by circularization of the linear viral genome. EMBO J 1988; 7: 769-774.

22 Brinkmann MM, Schulz TF. Regulation of intracellular signalling by the terminal membrane proteins of members of the Gammaherpesvirinae. J Gen Virol 2006; 87: 1047-1074.

23 Middeldorp JM, Brink AA, van den Brule AJ, Meijer CJ. Pathogenic roles for Epstein-Barr virus (EBV) gene products in EBV-associated proliferative disorders. Crit Rev Oncol Hematol 2003; 45: 1-36.

24 Miller CL, Burkhardt AL, Lee JH, Stealey B, Longnecker R, Bolen JB et al. Integral membrane protein 2 of Epstein-Barr virus regulates reactivation from latency through dominant negative effects on protein-tyrosine kinases. Immunity 1995; 2: 155-166.

25 Bultema R, Longnecker R, Swanson-Mungerson M. Epstein-Barr virus LMP2A accelerates MYC-induced Iymphomagenesis. Oncogene 2009 28: 1471-1476.

26 Portis T, Longnecker R. Epstein-Barr virus (EBV) LMP2A mediates B-lymphocyte survival through constitutive activation of the Ras/PI3K/ Akt pathway. Oncogene 2004; 23: 8619-8628.

27 Fish K, Chen J, Longnecker R. Epstein-Barr virus latent membrane protein 2A enhances MYC-driven cell cycle progression in a mouse model of $B$ Iymphoma. Blood 2014; 123: 530-540.

28 Rechsteiner MP, Bernasconi M, Berger C, Nadal D. Role of latent membrane protein 2 isoforms in Epstein-Barr virus latency. Trends Microbiol 2008; 16: 520-527.

29 Howe JG, Steitz JA. Localization of Epstein-Barr virus-encoded small RNAs by in situ hybridization. Proc Natl Acad Sci USA 1986; 83: 9006-9010.

30 Hamilton-Dutoit SJ, Raphael M, Audouin J, Diebold J, Lisse I, Pedersen C et al. In situ demonstration of Epstein-Barr virus small RNAs (EBER 1) in acquired immunodeficiency syndrome-related lymphomas: correlation with tumor morphology and primary site. Blood 1993; 82: 619-624

31 Pfeffer S, Zavolan M, Grasser FA, Chien M, Russo JJ, Ju J et al. Identification of virus-encoded microRNAs. Science 2004; 304 734-736.

32 Xing L, Kieff E. Epstein-Barr virus BHRF1 micro- and stable RNAs during latency III and after induction of replication. J Virol 2007; 81: 9967-9975.

33 Chen H, Huang J, Wu FY, Liao G, Hutt-Fletcher L, Hayward SD. Regulation of expression of the Epstein-Barr virus BamHI-A rightward transcripts. J Virol 2005; 79: 1724-1733.

34 Barth S, Pfuhl T, Mamiani A, Ehses C, Roemer K, Kremmer E et al. Epstein-Barr virus-encoded microRNA miR-BART2 down-regulates the viral DNA polymerase BALF5. Nucleic Acids Res 2008; 36: 666-675.

35 lizasa H, Wulff BE, Alla NR, Maragkakis M, Megraw M, Hatzigeorgiou A et al. Editing of Epstein-Barr virus-encoded BART6 microRNAs controls their dicer targeting and consequently affects viral latency. J Biol Chem 2010; 285: 33358-33370.

36 Lung RW, Tong JH, Sung YM, Leung PS, Ng DC, Chau SL et al. Modulation of LMP2A expression by a newly identified Epstein-Barr virus-encoded microRNA miR-BART22. Neoplasia 2009; 11 1174-1184.

37 Skalsky RL, Corcoran DL, Gottwein E, Frank CL, Kang D, Hafner M et al. The viral and cellular microRNA targetome in lymphoblastoid cell lines. PLoS Pathog 2012; 8: e1002484.

38 Seto E, Moosmann A, Gromminger S, Walz N, Grundhoff A, Hammerschmidt W. Micro RNAs of Epstein-Barr virus promote cell cycle progression and prevent apoptosis of primary human B cells. PLoS Pathog 2010; 6: e1001063.

39 Choy EY, Siu KL, Kok KH, Lung RW, Tsang CM, To KF et al. An EpsteinBarr virus-encoded microRNA targets PUMA to promote host cell survival. J Exp Med 2008; 205: 2551-2560.

40 Gatto G, Rossi A, Rossi D, Kroening S, Bonatti S, Mallardo M. EpsteinBarr virus latent membrane protein 1 trans-activates miR-155 transcription through the NF-kB pathway. Nucleic Acids Res 2008; 36 6608-6619. 
41 Forte E, Salinas RE, Chang C, Zhou T, Linnstaedt SD, Gottwein E et al. The Epstein-Barr virus (EBV)-induced tumor suppressor microRNA MiR-34a is growth promoting in EBV-infected B cells. J Virol 2012; 86: 6889-6898.

42 Rosato P, Anastasiadou E, Garg N, Lenze D, Boccellato F, Vincenti S et al. Differential regulation of miR-21 and miR-146a by Epstein-Barr virusencoded EBNA2. Leukemia 2012; 26: 2343-2352.

43 Dojcinov SD, Venkataraman G, Raffeld M, Pittaluga S, Jaffe ES. EBV positive mucocutaneous ulcer-a study of 26 cases associated with various sources of immunosuppression. Am J Surg Pathol 2010; 34: 405-417.

44 Cohen JI, Jaffe ES, Dale JK, Pittaluga S, Heslop HE, Rooney CM et al. Characterization and treatment of chronic active Epstein-Barr virus disease: a 28-year experience in the United States. Blood 2011; 117: 5835-5849.

45 Straus SE. The chronic mononucleosis syndrome. J Infect Dis 1988; 157: 405-412.

46 Cohen JI, Kimura H, Nakamura S, Ko YH, Jaffe ES. Epstein-Barr virusassociated lymphoproliferative disease in non-immunocompromised hosts: a status report and summary of an international meeting, 8-9 September 2008. Ann Oncol 2009; 20: 1472-1482.

47 Kimura H, Morishima T, Kanegane H, Ohga S, Hoshino Y, Maeda A et al. Prognostic factors for chronic active Epstein-Barr virus infection. J Infect Dis 2003; 187: 527-533.

48 Du MQ, Diss TC, Liu H, Ye H, Hamoudi RA, Cabecadas J et al. KSHV- and EBV-associated germinotropic Iymphoproliferative disorder. Blood 2002; 100: 3415-3418.

49 Nakamura S, Jaffe ES, Swerdlow SH (eds). EBV Positive Diffuse Large $B$-Cell Lymphoma of the Elderly. International Agency for Research on Cancer (IARC): Lyon, France, 2008.

50 Oyama T, Ichimura K, Suzuki R, Suzumiya J, Ohshima K, Yatabe Y et al. Senile EBV+ B-cell lymphoproliferative disorders: a clinicopathologic study of 22 patients. Am J Surg Pathol 2003; 27: 16-26.

51 Ok CY, Papathomas TG, Medeiros LJ, Young KH. EBV-positive diffuse large B-cell lymphoma of the elderly. Blood 2013; 122: 328-340.

52 Ok CY, Li L, Xu-Monette ZY, Visco C, Tzankov A, Manyam GC et al. Prevalence and clinical implications of Epstein-Barr virus infection in de novo diffuse large B-cell lymphoma in Western countries. Clin Cancer Res 2014; 20: 2338-2349.

53 Hofscheier A, Ponciano A, Bonzheim I, Adam P, Lome-Maldonado C, Vela $\mathrm{T}$ et al. Geographic variation in the prevalence of Epstein-Barr viruspositive diffuse large B-cell lymphoma of the elderly: a comparative analysis of a Mexican and a German population. Mod Pathol 2011; 24: 1046-1054.

54 Kuze T, Nakamura N, Hashimoto Y, Sasaki Y, Abe M. The characteristics of Epstein-Barr virus (EBV)-positive diffuse large B-cell lymphoma: comparison between $\mathrm{EBV}(+)$ and $\mathrm{EBV}(-)$ cases in Japanese population. Jpn J Cancer Res 2000; 91: 1233-1240.

55 Oyama T, Yamamoto K, Asano N, Oshiro A, Suzuki R, Kagami Y et al. Age-related EBV-associated B-cell lymphoproliferative disorders constitute a distinct clinicopathologic group: a study of 96 patients. Clin Cancer Res 2007; 13: 5124-5132.

56 Park S, Lee J, Ko YH, Han A, Jun HJ, Lee SC et al. The impact of EpsteinBarr virus status on clinical outcome in diffuse large B-cell lymphoma. Blood 2007; 110: 972-978.

57 Hoeller S, Tzankov A, Pileri SA, Went P, Dirnhofer S. Epstein-Barr viruspositive diffuse large B-cell lymphoma in elderly patients is rare in Western populations. Hum Pathol 2010; 41: 352-357.

58 Montes-Moreno S, Odqvist L, Diaz-Perez JA, Lopez AB, de Villambrosia SG, Mazorra F et al. EBV-positive diffuse large B-cell lymphoma of the elderly is an aggressive post-germinal center B-cell neoplasm characterized by prominent nuclear factor-kB activation. Mod Pathol 2012; 25: 968-982

59 Chan JKC, Aozasa K, Gaulard P (eds). DLBCL Associated with Chronic Inflammation. IARC: Lyon, France, 2008.

60 luchi K, Ichimiya A, Akashi A, Mizuta T, Lee YE, Tada H et al. NonHodgkin's lymphoma of the pleural cavity developing from long-standing pyothorax. Cancer 1987; 60: 1771-1775.

61 Nakatsuka S, Yao M, Hoshida Y, Yamamoto S, Iuchi K, Aozasa K. Pyothorax-associated lymphoma: a review of 106 cases. J Clin Oncol 2002; 20: 4255-4260.

62 Petitjean B, Jardin F, Joly B, Martin-Garcia N, Tilly H, Picquenot JM et al. Pyothorax-associated lymphoma: a peculiar clinicopathologic entity derived from $B$ cells at late stage of differentiation and with occasional aberrant dual B- and T-cell phenotype. Am J Surg Pathol 2002; 26: 724-732.

63 Yamato H, Ohshima K, Suzumiya J, Kikuchi M. Evidence for local immunosuppression and demonstration of c-myc amplification in pyothorax-associated lymphoma. Histopathology 2001; 39: 163-171.

64 Hongyo T, Kurooka M, Taniguchi E, Iuchi K, Nakajima Y, Aozasa K et al. Frequent p53 mutations at dipyrimidine sites in patients with pyothoraxassociated lymphoma. Cancer Res 1998; 58: 1105-1107.

65 Nishiu M, Tomita Y, Nakatsuka S, Takakuwa T, lizuka N, Hoshida Y et al. Distinct pattern of gene expression in pyothorax-associated lymphoma (PAL), a lymphoma developing in long-standing inflammation. Cancer Sci 2004; 95: 828-834.

66 Stein H, Harris NL, Campo E (eds). Plasmablastic Lymphoma. IARC: Lyon, France, 2008.

67 Delecluse HJ, Anagnostopoulos I, Dallenbach F, Hummel M, Marafioti T, Schneider $U$ et al. Plasmablastic lymphomas of the oral cavity: a new entity associated with the human immunodeficiency virus infection. Blood 1997; 89: 1413-1420.

68 Castillo J, Pantanowitz L, Dezube BJ. HIV-associated plasmablastic lymphoma: lessons learned from 112 published cases. Am J Hematol 2008; 83: 804-809.

69 Teruya-Feldstein J, Chiao E, Filippa DA, Lin O, Comenzo R, Coleman M et al. CD20-negative large-cell lymphoma with plasmablastic features: a clinically heterogenous spectrum in both HIV-positive and -negative patients. Ann Oncol 2004; 15: 1673-1679.

70 Hsi ED, Lorsbach RB, Fend F, Dogan A. Plasmablastic lymphoma and related disorders. Am J Clin Pathol 2011; 136: 183-194.

71 Isaacson PG, Campo E, Harris NL (eds). Large B-Cell Lymphoma Arising in HHV8-Associated Multicentric Castleman Disease. IARC: Lyon, France, 2008.

72 Valera A, Balague O, Colomo L, Martinez A, Delabie J, Taddesse-Heath L et al. IG/MYC rearrangements are the main cytogenetic alteration in plasmablastic lymphomas. Am J Surg Pathol 2010; 34: 1686-1694.

73 Said J, Cesarman E (eds). Primary Effusion Lymphoma. IARC: Lyon, France, 2008.

74 Nador RG, Cesarman E, Chadburn A, Dawson DB, Ansari MQ, Sald J et al. Primary effusion lymphoma: a distinct clinicopathologic entity associated with the Kaposi's sarcoma-associated herpes virus. Blood 1996; 88: 645-656.

75 Chadburn A, Hyjek E, Mathew S, Cesarman E, Said J, Knowles DM. KSHV-positive solid lymphomas represent an extra-cavitary variant of primary effusion lymphoma. Am J Surg Pathol 2004; 28: 1401-1416.

76 Jones D, Ballestas ME, Kaye KM, Gulizia JM, Winters GL, Fletcher J et al. Primary-effusion lymphoma and Kaposi's sarcoma in a cardiac-transplant recipient. New Engl J Med 1998; 339: 444-449.

77 Said JW, Tasaka T, Takeuchi S, Asou H, de Vos S, Cesarman E et al. Primary effusion lymphoma in women: report of two cases of Kaposi's sarcoma herpes virus-associated effusion-based lymphoma in human immunodeficiency virus-negative women. Blood 1996; 88: 3124-3128.

78 Cobo F, Hernandez S, Hernandez L, Pinyol M, Bosch F, Esteve J et al. Expression of potentially oncogenic HHV-8 genes in an EBV-negative primary effusion lymphoma occurring in an HIV-seronegative patient. J Pathol 1999; 189: 288-293.

79 Horenstein MG, Nador RG, Chadburn A, Hyjek EM, Inghirami G, Knowles $D M$ et al. Epstein-Barr virus latent gene expression in primary effusion lymphomas containing Kaposi's sarcoma-associated herpesvirus/human herpesvirus-8. Blood 1997; 90: 1186-1191.

80 Pan ZG, Zhang QY, Lu ZB, Quinto T, Rozenvald IB, Liu LT et al. Extracavitary KSHV-associated large B-cell lymphoma: a distinct entity or a subtype of primary effusion lymphoma? Study of 9 cases and review of an additional 43 cases. Am J Surg Pathol 2012; 36: 1129-1140.

81 Mullaney BP, Ng VL, Herndier BG, McGrath MS, Pallavicini MG. Comparative genomic analyses of primary effusion lymphoma. Arch Pathol Lab Med 2000; 124: 824-826.

82 Klein U, Gloghini A, Gaidano G, Chadburn A, Cesarman E, Dalla-Favera R et al. Gene expression profile analysis of AIDS-related primary effusion lymphoma (PEL) suggests a plasmablastic derivation and identifies PELspecific transcripts. Blood 2003; 101: 4115-4121.

83 Liebow AA, Carrington CR, Friedman PJ. Lymphomatoid granulomatosis. Hum Pathol 1972; 3: 457-558.

84 Pittaluga S, Wilson WH, Jaffe ES (eds). Lymphomatoid Granulomatosis. IARC: Lyon, France, 2008. 
85 Beaty MW, Toro J, Sorbara L, Stern JB, Pittaluga S, Raffeld M et al. Cutaneous lymphomatoid granulomatosis: correlation of clinical and biologic features. Am J Surg Pathol 2001; 25: 1111-1120.

86 Taniere $\mathrm{P}$, Thivolet-Bejui F, Vitrey D, Isaac S, Loire R, Cordier JF et al. Lymphomatoid granulomatosis-a report on four cases: evidence for $B$ phenotype of the tumoral cells. Eur Respir J 1998; 12: 102-106.

87 Katzenstein AL, Carrington CB, Liebow AA. Lymphomatoid granulomatosis: a clinicopathologic study of 152 cases. Cancer 1979; 43: 360-373.

88 Guinee D Jr., Jaffe E, Kingma D, Fishback N, Wallberg K, Krishnan J et al. Pulmonary lymphomatoid granulomatosis. Evidence for a proliferation of Epstein-Barr virus infected B-lymphocytes with a prominent T-cell component and vasculitis. Am J Surg Pathol 1994; 18: 753-764.

89 Burkitt D. A sarcoma involving the jaws in African children. Br J Surg 1958; 46: 218-223.

90 Leoncini L, Raphael M, Stein H, Harris NL, Jaffe E, Kluin PM (eds). Burkitt Lymphoma. IARC: Lyon, France, 2008.

91 Morrow RH, Kisuule A, Pike MC, Smith PG. Burkitt's lymphoma in the Mengo Districts of Uganda: epidemiologic features and their relationship to malaria. J Nat/ Cancer Inst 1976; 56(3): 479-483.

92 Hummel M, Bentink S, Berger H, Klapper W, Wessendorf S, Barth TF et al. A biologic definition of Burkitt's lymphoma from transcriptional and genomic profiling. New Eng/ J Med 2006; 354: 2419-2430.

93 Victora GD, Dominguez-Sola D, Holmes AB, Deroubaix S, Dalla-Favera R, Nussenzweig MC. Identification of human germinal center light and dark zone cells and their relationship to human B-cell lymphomas. Blood 2012; 120: 2240-2248.

94 Lenze D, Leoncini L, Hummel M, Volinia S, Liu CG, Amato T et al. The different epidemiologic subtypes of Burkitt lymphoma share a homogenous micro RNA profile distinct from diffuse large B-cell lymphoma. Leukemia 2011; 25: 1869-1876.

95 Schmitz R, Young RM, Ceribelli M, Jhavar S, Xiao W, Zhang M et al. Burkitt lymphoma pathogenesis and therapeutic targets from structural and functional genomics. Nature 2012; 490: 116-120.

96 Richter J, Schlesner M, Hoffmann S, Kreuz M, Leich E, Burkhardt B et al. Recurrent mutation of the ID3 gene in Burkitt lymphoma identified by integrated genome, exome and transcriptome sequencing. Nat Genet 2012; 44: 1316-1320.

97 Love C, Sun Z, Jima D, Li G, Zhang J, Miles R et al. The genetic landscape of mutations in Burkitt lymphoma. Nat Genet 2012; 44: 1321-1325.

98 Hodgkin T. On some morbid appearances of the absorbent glands and spleen. Med Chir Trans 1832; 17: 68-114.

99 Delsol G, Brousset P, Chittal S, Rigal-Huguet F. Correlation of the expression of Epstein-Barr virus latent membrane protein and in situ hybridization with biotinylated BamHI-W probes in Hodgkin's disease. Am J Pathol 1992; 140: 247-253.

100 Marafioti T, Hummel M, Foss HD, Laumen H, Korbjuhn P, Anagnostopoulos I et al. Hodgkin and Reed-Sternberg cells represent an expansion of a single clone originating from a germinal center B-cell with functional immunoglobulin gene rearrangements but defective immunoglobulin transcription. Blood 2000; 95: 1443-1450.

101 Hartmann S, Martin-Subero JI, Gesk S, Husken J, Giefing M, Nagel I et al. Detection of genomic imbalances in microdissected Hodgkin and Reed Sternberg cells of classical Hodgkin's lymphoma by array-based comparative genomic hybridization. Haematologica 2008; 93: 1318-1326.

102 Steidl C, Diepstra A, Lee T, Chan FC, Farinha P, Tan K et al. Gene expression profiling of microdissected Hodgkin Reed-Sternberg cells correlates with treatment outcome in classical Hodgkin lymphoma. Blood 2012; 120: 3530-3540.

103 Sanchez-Espiridion B, Martin-Moreno AM, Montalban C, Figueroa V, Vega $\mathrm{F}$, Younes $\mathrm{A}$ et al. MicroRNA signatures and treatment response in patients with advanced classical Hodgkin lymphoma. $\mathrm{Br} J$ Haematol 2013; 162: 336-347.

104 Swerdlow SH, Webber SA, Chadburn A, Ferry JA (eds). Post-transplant Lymphoproliferative Disorders. IARC: Lyon, France, 2008.

105 Doak PB, Montgomerie JZ, North JD, Smith F. Reticulum cell sarcoma after renal homotransplantation and azathioprine and prednisone therapy. Br Med J 1968; 4: 746-748.

106 Opelz G, Dohler B. Lymphomas after solid organ transplantation: a collaborative transplant study report. Am J Transplant 2004; 4: 222-230.
107 McDonald RA, Smith JM, Ho M, Lindblad R, Ikle D, Grimm P et al. Incidence of PTLD in pediatric renal transplant recipients receiving basiliximab, calcineurin inhibitor, sirolimus and steroids. Am J Transplant 2008; 8: 984-989.

108 Sebelin-Wulf K, Nguyen TD, Oertel S, Papp-Vary M, Trappe RU, Schulzki A et al. Quantitative analysis of EBV-specific CD4/CD8 T cell numbers, absolute CD4/CD8 T cell numbers and EBV load in solid organ transplant recipients with PLTD. Transp/ Immunol 2007; 17: 203-210.

109 Vakiani E, Nandula SV, Subramaniyam S, Keller CE, Alobeid B, Murty VV et al. Cytogenetic analysis of B-cell posttransplant lymphoproliferations validates the World Health Organization classification and suggests inclusion of florid follicular hyperplasia as a precursor lesion. Hum Pathol 2007; 38: 315-325.

110 Djokic M, Le Beau MM, Swinnen LJ, Smith SM, Rubin CM, Anastasi J et al. Post-transplant lymphoproliferative disorder subtypes correlate with different recurring chromosomal abnormalities. Genes Chromosomes Cancer 2006; 45: 313-318.

111 Rinaldi A, Kwee I, Poretti G, Mensah A, Pruneri G, Capello D et al. Comparative genome-wide profiling of post-transplant lymphoproliferative disorders and diffuse large B-cell lymphomas. Br J Haematol 2006; 134: 27-36.

112 Morscio J, Dierickx D, Ferreiro JF, Herreman A, Van Loo P, Bittoun E et al. Gene expression profiling reveals clear differences between EBV-positive and EBV-negative posttransplant lymphoproliferative disorders. Am J Transplant 2013; 13: 1305-1316.

113 Rossi D, Gaidano G, Gloghini A, Deambrogi C, Franceschetti S, Berra E et al. Frequent aberrant promoter hypermethylation of $0^{6}$-methylguanineDNA methyltransferase and death-associated protein kinase genes in immunodeficiency-related lymphomas. $\mathrm{Br} J$ Haematol 2003; 123 475-478.

114 Alsayed Y, Leleu X, Leontovich A, Oton AB, Melhem M, George D et al. Proteomics analysis in post-transplant lymphoproliferative disorders. Eur J Haematol 2008; 81: 298-303.

115 Abruzzo LV, Rosales CM, Medeiros LJ, Vega F, Luthra R, Manning JT et al. Epstein-Barr virus-positive B-cell lymphoproliferative disorders arising in immunodeficient patients previously treated with fludarabine for low-grade B-cell neoplasms. Am J Surg Pathol 2002; 26: 630-636.

116 Ghobrial IM, Otteman LA, White WL. An EBV-positive lymphoproliferative disorder after therapy with alemtuzumab. New Eng/ J Med 2003; 349: 2570-2572; discussion 2570-2572.

117 Sohani AR, Ferry JA, Chang PS, Abramson JS. Epstein-Barr virus-positive diffuse large B-cell lymphoma during therapy with alemtuzumab for T-cell prolymphocytic leukemia. J Clin Oncol 2010; 28 e69-e72.

118 Hasserjian RP, Chen S, Perkins SL, de Leval L, Kinney MC, Barry TS et al. Immunomodulator agent-related lymphoproliferative disorders. Mod Pathol 2009; 22: 1532-1540.

119 Kikuchi K, Miyazaki Y, Tanaka A, Shigematu H, Kojima M, Sakashita H et al. Methotrexate-related Epstein-Barr virus (EBV)-associated lymphoproliferative disorder-so-called 'Hodgkin-like lesion' - of the oral cavity in a patient with rheumatoid arthritis. Head Neck Pathol 2010; 4: 305-311.

120 Bhamidipati PK, Jabbour E, Konoplev S, Estrov Z, Cortes J, Daver N. Epstein-Barr virus-induced CD30-positive diffuse large B-cell lymphoma in a patient with mixed-phenotypic leukemia treated with clofarabine. Clin Lymphoma Myeloma Leuk 2013; 13: 342-346.

This work is licensed under a Creative Commons Attribution 3.0 Unported License. The images or other third party material in this article are included in the article's Creative Commons license, unless indicated otherwise in the credit line; if the material is not included under the Creative Commons license, users will need to obtain permission from the license holder to reproduce the material. To view a copy of this license, visit http:// creativecommons.org/licenses/by/3.0/ 